\title{
Classes Médias no Brasil: Do que se Trata? Qual seu Tamanho? Como Vem Mudando?*
}

\author{
Adalberto Cardoso ${ }^{1}$ \\ Edmond Préteceille ${ }^{2}$
}

${ }^{1}$ Universidade do Estado do Rio de Janeiro (UERJ), Rio de Janeiro, RJ, Brasil. E-mail: acardoso@iesp.uerj.br

${ }^{2}$ Centre National de la Recherche Scientifique (CNRS), Paris, França. E-mail:

edmond.preteceille@sciencespo.fr

\section{APRESENTAÇÃO}

Tá há alguns anos, pesquisadores de todo o mundo têm devotado atenção à mobilidade social ascendente de parcelas expressivas das populações dos países em desenvolvimento, ou "emergentes". A mobilidade seria um resultado "natural", mas longa e frustrantemente aguardado, do desenvolvimento capitalista mundial, agora finalmente estendido à periferia do sistema. China, Índia, África do Sul, Turquia, Brasil, Argentina, Chile, México, Colômbia e a maioria dos demais países de renda média estariam passando por mudanças estruturais importantes que, em associação ou não com políticas públicas redistributivas, estariam retirando centenas de milhões de pessoas da condição de pobreza. Estaríamos diante de uma "nova classe média" global, que, por várias razões, passou a interessar os organismos internacionais (como o Banco Mundial, as Nações Unidas e suas agências, e a Organização para a Cooperação e Desenvolvimento Econômico -

\footnotetext{
* Agradecemos os comentários de Wanderley Guilherme dos Santos a versão anterior deste artigo, e também aos dois pareceristas anônimos de DADOS - Revista de Ciências Sociais. A pesquisa de que este trabalho resulta recebeu apoios financeiros do programa Coordenação de Aperfeiçoamento de Pessoal de Nível Superior (CAPES)/COFECUB para a cooperação entre os autores; e do Conselho Nacional de Desenvolvimento Científico e Tecnológico (CNPq) (bolsa PQ 1B), da Fundação Carlos Chagas Filho de Amparo à Pesquisa do Estado do Rio de Janeiro (Faperj) (bolsa Cientista do Nosso Estado) e da Universidade do Estado do Rio de Janeiro (UERJ) (bolsa Pró-Ciência), concedidos a Adalberto Cardoso.
}

DADOS - Revista de Ciências Sociais, Rio de Janeiro, vol. 60, n-4, 2017, pp. 977 a 1023. 
OCDE), a academia (particularmente os economistas), os meios de comunicação de massa e os formuladores de políticas públicas ${ }^{1}$.

O interesse dos diferentes agentes e pesquisadores tem múltiplas formas. Alguns, como Souza e Lamounier (2010) e boa parte da literatura que louva a emergência da "nova classe média", veem nela "um pilar decisivo da democracia e da economia de mercado" (idem:19), por ser (segundo o argumento) mais educada, mais propensa à participação civil e à busca de maior nível de informação, o que aumentaria sua capacidade de compreensão da dinâmica política mais geral ${ }^{2}$. Ela seria mais empreendedora e mais voltada ao investimento em seu capital humano e à acumulação de ativos, com isso sendo ideologicamente mais moderada. Outros se preocupam com a relação entre as classes médias e a dinâmica econômica, especialmente sua capacidade de sustentar um crescimento continuado da riqueza nacional ${ }^{3}$. Outros, ainda, investigam o impacto do crescimento dos setores médios na demanda por serviços públicos de qualidade e por seguridade social no futuro, e, portanto, estão preocupados com os novos desafios que o crescimento das classes médias representa para o contrato social e as políticas públicas ${ }^{4}$. Um amplo espectro de pesquisadores se interessa, ainda, pela identificação dos padrões de transformação na estrutura social e de classes, dos padrões de mobilidade social e de promoção das condições de vida e trabalho das maiorias e temas correlatos, que nos ocuparão mais de perto. E não podemos esquecer, no caso do Brasil, que o alegado surgimento da "nova classe média" foi politicamente mobilizado pelos governos do Partido dos Trabalhadores (PT) como prova do sucesso de suas políticas de inclusão social (Singer, 2009; Ricci, 2013). A atenção devotada às classes médias, pois, mobiliza múltiplas energias de pesquisadores, opinião pública e agentes estatais, por razões diversas e nem sempre convergentes.

No Brasil, o interesse pelo tema foi reavivado pelos estudos de Marcelo Neri (2008 e 2010) sobre a "nova classe média brasileira", que provocaram intenso debate. As reações mobilizaram investigadores das mais diversas disciplinas das ciências sociais, e as críticas vieram de todos os lados. Neste trabalho, nós nos somaremos ao grupo dos críticos, mas não, talvez, pelas mesmas razões, já que, ainda que apontemos suas limitações, reconheceremos mérito à abordagem de Neri e da comunidade de pesquisadores que, mundialmente, adota a mesma metodologia. E pretendemos oferecer algo em troca, isto é, proporemos uma metodologia própria de análise da mudança recente na estrutura 
social brasileira, na qual a renda, obviamente importante, surgirá como o resultado de dinâmicas econômicas e sociais mais profundas. Nossa tese é a de que houve, de fato, notável mudança na estrutura de classes do país nos últimos anos, mas tal mudança está muito distante de revelar "o lado brilhante dos pobres", subtítulo da segunda versão de Neri para o mesmo argumento (publicada em 2010).

Formulando na interrogativa: até que ponto a melhoria nas condições de vida no país resultou de mudanças na estrutura de posições de trabalhadores e trabalhadoras na divisão social do trabalho, a ponto de podermos sustentar que o Brasil é, hoje, um país de classe média?

Para responder a essa questão, o artigo está dividido em seis seções, além desta introdução. Na próxima seção, discutimos brevemente a literatura internacional e nacional sobre classes médias, mostrando que o debate é antigo e recorrente, mas seus eixos centrais não têm sido devidamente tomados em conta pela literatura mais recente. Na seção seguinte, concordamos com os que salientam a inequívoca expansão da capacidade de consumo de um vasto contingente populacional na última década e meia, mas argumentamos que tomar apenas a renda como indicador de oportunidades de vida (ou posições de classe) de indivíduos e famílias é reduzir a complexa teia de condicionantes daquelas oportunidades a um de seus elementos, que é, lógica e empiricamente, posterior às qualificações profissionais de homens e mulheres e à sua capacidade de as fazer valer no mercado de trabalho. É o que propomos na terceira seção: filiando-nos à tradição aberta pelos estudos de C. W. Mills, argumentamos que, contrariamente ao que sustenta a literatura sobre a alegada fluidez da modernidade, o trabalho ainda é central na vida daqueles que obtêm meios de vida por meio da venda de sua força de trabalho. Logo, a estrutura ocupacional ainda é o principal "componente causal de oportunidades de vida" das classes que vivem de seu trabalho, como é o caso da maioria das classes médias. Propomos, então, uma estrutura de classes coextensiva à divisão do trabalho, utilizando para isso a Classificação Brasileira de Ocupações (CBO), traduzida numa adaptação para o Brasil das Categorias Socioprofissionais francesas, cujo desenho é mais sensível às classes médias do que alternativas disponíveis, discutidas rapidamente no texto. Ainda na mesma seção comparamos nossa classificação com a proposta por Marcelo Neri, e mostramos que parte bastante minoritária da classe C pertence efetivamente às classes médias definidas segundo a ocupação. 
Nas seções quatro e cinco, analisamos a evolução da estrutura brasileira de classes entre 2002 e 2014, primeiro tomando as classes médias em sua relação com as demais classes da categorização proposta, e em seguida analisando as mudanças internas às camadas médias. Mostramos que as classes médias de fato cresceram substancialmente no período, mas o crescimento foi mais acentuado nas regiões metropolitanas, com destaque para São Paulo. Ainda assim, fica claro que o Brasil está muito longe de se constituir num país de classe média. Na conclusão, resumimos o argumento.

\section{UM BREVE BALANÇO DA LITERATURA}

As pesquisas atuais sobre classes médias são a metamorfose de um interesse antigo, que se renova de tempos em tempos em razão de transformações econômicas, movimentos contestatórios, eventos políticos ou modas acadêmicas. O texto clássico de Charles Wright Mills, por exemplo, sobre a "nova classe média americana", ou os trabalhadores de "colarinho branco", foi publicado em 1951, e recupera vários trabalhos do autor escritos ao longo da década de 1940, além de estudos de colegas produzidos nos anos 1920 e 1930 nos Estados Unidos, Alemanha e Inglaterra. Logo, o interesse já vinha de longe. A erosão da classe média tradicional americana, proprietária de pequenos negócios no campo ou na cidade, responsável pela construção da nação e esteio do liberalismo constitutivo da política e das relações econômicas e sociais do país, é recuperada com certa nostalgia pela sociologia americana do entreguerras, Mills inclusive, que vê na grande empresa e na crescente regulação estatal da vida econômica e social do país um processo (inelutável) de burocratização da vida, à moda da "jaula de ferro" de Weber.

Esse clássico continua pautando, de um modo ou de outro, a pesquisa sociológica sobre as classes médias. Estão lá temas como mobilidade social ${ }^{5}$, heterogeneidade estrutural dos white collar, vulnerabilidade de seus estratos mais baixos ${ }^{6}$, medo da desclassificação (ou perda de status $)^{7}$, inflação de credenciais provocando insegurança de renda ${ }^{8}$, fontes e mecanismos de obtenção e garantia de prestígio e distinção", relação com as outras classes ${ }^{10}$, participação e valores políticos ${ }^{11} \mathrm{e}$ muito mais.

Diferentemente, porém, da onda atual de estudos, o trabalho de Wright Mills e a tradição que ele ajudou a consolidar definem classe 
social a partir da posição das pessoas na estrutura social, que reflete a divisão social do trabalho. Mills recupera Weber e a ideia de classe como "componente causal de oportunidades de vida", oportunidades que não estão igualmente distribuídas entre as pessoas, pois os lugares que ocupam na divisão do trabalho configuram distintas probabilidades de destino (ou de trajetória) social ${ }^{12}$.

É nessa tradição que a discussão sociológica sobre as classes médias ganhou relevo nos anos 1960-70 na Europa e, particularmente, na França. O período foi de apogeu e declínio dos "trinta gloriosos", nos quais o crescimento da economia, o incremento importante das inovações tecnológicas e a expansão das políticas públicas produziram aumento expressivo daquelas classes. Alguns autores interpretaram esse aumento como expansão de uma "nova pequena burguesia" (Baudelot et al. 1974; Poulantzas, 1974), conforme o esquema marxista tradicional, enquanto outros viram nele a emergência de uma nova categoria de assalariados suscetíveis de constituir novos atores sociais no mundo do trabalho - muitos sindicatos operários tentaram atraí-los-, na cultura e na transformação dos modos de vida, e também na política. Mendras (1988), por exemplo, discute essas diferentes dimensões e se interroga sobre os movimentos de aproximação e distanciamento dos diferentes estratos dessas novas classes médias em relação aos grandes polos sociais e políticos constituídos pelas classes tradicionais, a classe capitalista e a classe operária. Se sua hipótese predileta, aquela da "medianização da sociedade", foi invalidada pela história, suas análises continuam relevantes por sua multidimensionalidade. Mais recentemente o interesse de pesquisa tem privilegiado a fragilização e o medo da desclassificação das camadas médias ${ }^{13}$.

\section{CLASSES MÉDIAS NO BRASIL}

No Brasil o interesse sistemático pelas classes médias urbanas é mais recente, em parte porque o fenômeno empírico ganhou momentum apenas nos anos 1970, em razão das intensas industrialização e urbanização, e em parte porque as ciências sociais brasileiras dedicaram suas melhores energias a compreender a mudança social, com foco, sobretudo, na pobreza e nos modos de vida, trabalho, ação coletiva e simbolização das classes populares, que o capitalismo emergente vinha transformando. Até muito recentemente, contavam-se nos dedos os autores dedicados ao tema. Não podemos ser exaustivos na apresenta- 
ção da configuração desse campo de estudos no país, mas cabe apontar alguns trabalhos relevantes.

Entre os pioneiros estão a pesquisa de Décio Saes (1975), sobre classe média e política na Primeira República, e a coletânea coordenada por J.A.G. Albuquerque, publicada em 1977 e que traz contribuições de Alain Touraine, Fernando Henrique Cardoso, Gilberto Velho e outros, também sobre a mesma relação, porém no período contemporâneo aos autores (Albuquerque, 1977) ${ }^{14}$. Ambas, portanto, trazendo preocupação que já estava em Wright Mills (como o papel das classes médias na erosão dos padrões tradicionais e oligárquicos de dominação), e que permanece importante na produção posterior (como em Simões, 1985).

Nos anos 1980 um ainda frágil campo de estudos sobre classes médias, em chave próxima à de Wright Mills, começa a se delinear no país. São importantes a pioneira dissertação de mestrado de Waldir Quadros (1985) e a tese de doutorado de Romanelli (1986), ambas de meados da década. Quadros, um economista, mantém-se na tradição consolidada por Mills: preocupado com as mudanças na estratificação social, define classes médias a partir de sua posição na divisão do trabalho e constrói uma tipologia de posições de classe com base nas ocupações capturadas pelas pesquisas domiciliares do Instituto Brasileiro de Geografia e Estatística (IBGE). Porém, essa dissertação e a tese de doutorado do mesmo autor, de 1991 (sobre o surgimento de uma nova classe média em razão do "Milagre Brasileiro" nos anos $1970^{15}$ ), demorariam ainda alguns anos para animar o debate acadêmico mais amplo, já que nunca foram publicadas, assim como não o foi a tese de Romanelli, sintoma do exíguo interesse que o tema despertava no país. Nos dois casos há a reivindicação da importância de se estudar as classes médias para a compreensão das dinâmicas social e política do Brasil, para não falar de sua eventual centralidade na sustentabilidade da democracia.

Esses estudos estavam em linha com as emergentes pesquisas sobre estratificação social no país, como Singer $(1981,1988)$ e, um pouco antes, Pastore (1979) que não estavam, porém, preocupados especificamente com as classes médias, e sim com as mudanças na estrutura de classes como um todo e, no caso do último autor, particularmente com a mobilidade social num Brasil em processo de urbanização (tema que seria retomado em Pastore e Silva, 2000). Mobilizando grandes bases de dados (censos e pesquisas amostrais do IBGE), os estudos mostraram o aumento gradativo (embora pequeno) da fluidez social da sociedade 
brasileira, com o fechamento das posições superiores e o aumento da mobilidade circular (ou horizontal) das camadas médias inferiores.

Na mesma década tem início a delimitação das profissões de classe média como objeto sistemático de pesquisa, utilizando sobretudo metodologias qualitativas. Como mostram Bonelli e Donatoni (1996), dos 116 trabalhos catalogados em seu exaustivo levantamento bibliográfico para o período 1980-1994, 77 foram publicados nos anos $1980^{16}$, grande parte sendo dissertações de mestrado, teses de doutorado e textos apresentados em congressos acadêmicos, alguns jamais publi$\operatorname{cados}^{17}$. As autoras atribuem o interesse das ciências sociais sobre o tema a aspectos como a saliência das greves do funcionalismo público na transição para a democracia, a perda de prestígio profissional decorrente do assalariamento crescente dos profissionais liberais e a queda de seu padrão de vida.

Essa incipiente efervescência investigativa encontrou em Oliveira (1987) uma tentativa de teorização (marxista) das classes médias, que escapasse da armadilha marxiana clássica que via nos setores médios de seu tempo (a pequena burguesia) um estrato social transitório, destinado, cedo ou tarde, ou à proletarização ou à ascensão a posições burguesas, num movimento, para Marx inexorável, de simplificação da estrutura de classes no capitalismo que terminaria por opor explorados e exploradores, sem setores intermediários. Oliveira reconhece a complexidade da dinâmica capitalista contemporânea, a emergência dos estados de bem-estar e seus exércitos de servidores públicos com status diverso dos proletários clássicos, a consolidação dos estratos profissionais, das gerências capitalistas etc., e, portanto, a metamorfose dos setores médios, não mais proprietários, mas de modo algum destinados a sucumbir ante o crescimento fagocitário das classes típicas do capitalismo (proletários e burgueses). O interesse do exercício de Oliveira está, sobretudo, na tentativa de delimitar as classes médias em suas relações com as demais classes, e portanto nas relações de identificação, alteridade, negação e conflito que tornam seus interesses, em determinado momento de sua constituição, irredutíveis aos das outras classes. Ele tenta, pois, fundar a necessidade teórica das classes médias no momento atual do capitalismo.

Nos anos 1990, os estudos sobre classes médias ganham densidade no Brasil, configurando propriamente um campo de pesquisas. De um lado, entra em tela de juízo a reestruturação industrial, que, como nos 
países avançados uma década antes, começa a destruir postos de trabalho das gerências intermediárias das grandes corporações, que, por seu lado, dão início ao processo de desverticalização da produção. Têm início as terceirizações de segmentos inteiros das fábricas e grandes empresas, a transformação de gerentes em consultores subcontratados, a eliminação pura e simples de postos gerenciais na "empresa enxuta" etc., aspectos dos quais se ocupa a sociologia do trabalho interessada nos processos de reestruturação produtiva ${ }^{18}$. De outro lado, aprofunda-se a pesquisa sobre a eventual proletarização dos profissionais liberais, no âmbito da sociologia das profissões ${ }^{19}$.

Essas novas frentes de investigação vêm se somar à tradição, iniciada nos anos 1980, dos estudos de estratificação e desigualdades sociais, que ganham volume e extensão no território brasileiro. Surgem pesquisas sobre estratos médios segundo cor ou raça (Figueiredo, 2009), sobre camadas médias emergentes e privilegiadas (Lima, 2008), sobre a segregação espacial nas metrópoles segundo os estratos de classe (Préteceille e Ribeiro, 1999; Marques et al. 2008). São importantes, também, os novos trabalhos de Quadros (e.g. 2007 e 2008) sobre estratos médios, de Ribeiro e Scalon (2001) sobre mobilidade de classe, com atenção importante aos estratos médios, de Silva (2004) e, muito particularmente, o seminal Hasenbalg e Silva (2003), dentre centenas de outros.

Ganha vulto ainda, principalmente entre os economistas (e dentre eles os profissionais do IPEA), a pesquisa sobre desigualdades de renda que, de um modo ou de outro, passou a se ocupar, se bem que não centralmente, com a apropriação da renda pelas camadas médias. Dizemos "não centralmente" porque, para os nossos propósitos, os trabalhos dedicados ao estudo da distribuição de renda apresentam importante limitação metodológica. Os índices mais utilizados de desigualdade são, de fato, cegos em relação às classes médias. De um modo geral, está-se interessado na razão entre algum estrato de renda muito alto $(10 \%$ mais ricos, $5 \%, 1 \%)$ e um estrato muito baixo $(10 \%$ mais pobres, $20 \%, 40 \%$ ), e diz-se que os $10 \%$ mais ricos se apropriam de $X$ vezes a renda apropriada pelos $40 \%$ mais pobres, valor que é passível de comparações internacionais etc.. Nenhum desses estratos corresponde ao que a literatura econômica atual, da moda, entende como "classe média".

Assim, quando o trabalho de Marcelo Neri sobre a "nova classe média" vem a público em 2008, o Brasil já tinha consolidado considerável volume de conhecimento sobre nossa estrutura de classes e o lugar das 
classes médias nela, tradição que foi simplesmente desconsiderada por Neri.

Não há espaço, neste estudo, para mapear o debate que se seguiu à publicação dos textos de Neri. A literatura já é bastante alentada e suficientemente crítica $^{20}$. Interessa-nos, antes, chamar a atenção para alguns dos seus limites, se o que se quer é apreender o fenômeno, real e incontestável, da mudança social que o país viveu nos últimos anos, em especial no período 2002-2014, nosso recorte temporal de interesse.

\section{Constatações Importantes, mas Reducionistas}

De fato, parte-se aqui de uma constatação incontornável: houve inequívoca expansão da capacidade de consumo de parcelas expressivas da população brasileira, decorrente de uma associação complexa de fatores, dentre os quais se destacam: a geração de 20 milhões de empregos formais entre dezembro de 2003 e dezembro de $2014^{21}$; o aumento da renda do trabalho, tanto aquela indexada ao salário mínimo quanto a renda negociada pelos sindicatos (pisos salariais das categorias profissionais) $)^{22}$; o aumento real de $100 \%$ do salário mínimo entre janeiro/2003 e janeiro $/ 2015^{23}$, que beneficiou diretamente servidores públicos das regiões mais pobres do país (prefeituras e governos pagam o salário mínimo a parcela importante de seus servidores), parte expressiva dos aposentados e pensionistas $(60 \%$ dos quais ganham o salário mínimo ${ }^{24}$ ) e assalariados informais que têm sua renda de um modo ou de outro referenciada no salário mínimo, além dos assalariados formais que têm essa renda; o aumento da renda de ocupações por conta própria $^{25}$, resultante do aumento da massa salarial e da capacidade de consumo dos assalariados ${ }^{26}$; as transferências de renda por meio de políticas públicas como o Bolsa Família e o Benefício de Prestação Continuada ${ }^{27}$ (indexado ao salário mínimo); e os mecanismos variados de crédito ao consumidor, que permitiram aos trabalhadores de menor renda acesso a bens de consumo duráveis, entre eles automóveis e, muito particularmente, a casa própria.

A melhoria das condições de vida decorrente, sobretudo, do aumento dos empregos formais e da renda, abriu efetivas oportunidades de mobilidade ascendente (de renda) para parcelas extensas da população. $\mathrm{O}$ movimento objetivo foi captado pelas estatísticas e analisado pelas ciências sociais brasileiras, em sintonia com o que vem ocorrendo na maioria dos países emergentes. Tudo isso é incontestável. No que se 
refere, porém, às classes médias, qual a real dimensão dessa mudança, ou melhor, até que ponto a melhoria nas condições de vida no país resultou de mudanças na estrutura de posições de trabalhadores e trabalhadoras na divisão social do trabalho?

As abordagens que tomam a renda como medida exclusiva da mudança são insatisfatórias para responder essa pergunta, como já mostrou parte da literatura mencionada. Tome-se, por exemplo, uma renda familiar de $\mathrm{R} \$ 3.000$, que atende ao critério mais comum da classe $C$ de consumo, ou a "nova classe média" de Neri (2008). Essa renda não significa a mesma coisa para as diversas famílias (chefiadas por homens ou mulheres, jovens ou velhos, negros ou brancos, nucleares ou extensas, com ou sem filhos ou com muitos filhos; cujos responsáveis trabalham em empresa pública ou privada; que são professores ou policiais ou enfermeiros ou engenheiros bem ou mal formados, em início ou meio de carreira; que moram no campo ou em cidades pequenas ou médias ou numa megalópole, onde existe ou não oferta adequada, pública ou privada, de equipamentos urbanos de saúde, educação, transporte, habitação; que são ou não proprietárias de suas casas...) que eventualmente a auferem. Essa simples enumeração das complexas injunções sociais que definem as oportunidades e o ser social de uma família deixam claro que a renda de $\mathrm{R} \$ 3.000$ só pode ser um bom preditor de padrões gerais de consumo e bem estar sob determinadas condições, que, contudo, não estão pressupostas na afirmação de que essa renda define, sem mais, uma família de classe média. Ela simplesmente não defi$n e$, nem mesmo se o foco estiver exclusivamente na capacidade de consumo das famílias. Em outras palavras, tomar a renda familiar total como medida do bem-estar relativo das famílias e de sua estrutura de oportunidades, sem ter em conta aquelas injunções, é pensar no campo da pura ficção econômica.

\section{NOSSO RECORTE ANALÍTICO}

Posta nos termos do penúltimo parágrafo, a pergunta que nos move neste trabalho já indica os elementos de nossa opção teórica: nos filiamos, aqui, à tradição de estudos sociológicos que, no Brasil e alhures, compreende a estrutura de classes como expressão da complexa rede de posições sociais resultantes (e constitutivas) dos processos econômicos e sociais de produção, circulação e distribuição da riqueza, dos bens culturais, dos serviços públicos, do poder e do prestígio social que, em seu movimento, que é também o movimento da acumulação 
capitalista e da disputa pela distribuição da riqueza produzida, constituem e delimitam as oportunidades de inscrição social de homens e mulheres que vivem de seu trabalho. Esses processos não são indiferentes a clivagens sociais de raça, gênero, idade, habilidades físicas ou qualificações adquiridas ao longo da vida. Nem à distribuição das pessoas pelo espaço urbano e pelas regiões do país. Ao contrário. Em muitos sentidos, a acumulação capitalista se alimenta dessas clivagens e da competição entre os que elas classificam e ordenam. E homens e mulheres atuam diretamente sobre essas classificações e ordenamentos para transformar suas oportunidades de vida e também de seus filhos.

A renda, vale à pena insistir, é apenas um (embora, obviamente, muito importante) dos instrumentos, ou meios da ação social que visa a essa transformação. Outro instrumento, lógica e empiricamente anterior à renda auferida, são as qualificações profissionais e a capacidade que cada qual tem de as fazer valer diante de outros com as mesmas credenciais. Mercado objetivo de posições, competição pelas posições existentes, luta por manter-se nelas e eventualmente melhorá-las ou transformá-las ou mesmo destruí-las em favor de melhores posições: a renda é o resultado desse complexo processo, mas o captura apenas em parte, como uma espécie de medida do sucesso ou fracasso da luta por posições, que nada mais é do que uma das formas da luta de classes. A estrutura ocupacional, mimese da divisão do trabalho, é também a confluência de boa parte das injunções que definem as oportunidades de vida.

Ainda assim, é preciso reconhecer méritos ao estudo de Neri (2008 e 2010), que, aplicando metodologia consagrada internacionalmente ${ }^{28}$, chamou a atenção para a mobilidade econômica dos estratos inferiores de renda no país. O processo de ascensão social expresso no aumento da capacidade de consumo foi real, e atingiu todo o mundo "emergente", incluindo o Brasil. E sabemos desde Veblen, passando por Parsons, Wright Mills e Bourdieu, que o consumo diferenciado é um dos elementos distintivos do que entendemos por classes médias. Além disso, o estudo de Neri deu visibilidade aos estratos mais baixos das classes médias, num país no qual o termo costuma trazer à mente, em geral, $\mathrm{o}$ topo da distribuição de renda: gerentes, profissionais liberais, pessoal

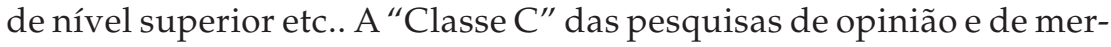
cado é uma ficção sociológica, mas por trás dela se esconde uma parte das "reais" classes médias inferiores (baixa e média), que são também objeto deste estudo. 


\section{A CENTRALIDADE DA OCUPAÇÃO}

Ao longo dos últimos decênios, um segmento da sociologia perdeu o interesse pela posição das pessoas e grupos sociais na divisão social do trabalho, e construiu teorias sobre o fim das estruturas sociais e mesmo da sociedade, colocando no lugar a fluidez das identidades, que poderiam, hoje, ser escolhidas livremente pelos agentes nos novos repertórios culturais (Urry, 2000; Baumann, 2003). Na discussão sobre as classes médias, parte desses autores justifica a mudança do eixo dos debates em direção à cultura, às identidades etc., a partir do alegado enfraquecimento dos laços entre a ocupação, ou a posição socioeconômica, de um lado, e de outro os modos de vida, as identidades, as trajetórias pessoais e as estruturas de oportunidades.

Essa hipótese, muitas vezes aceita como evidente, confunde, parecenos, dois processos distintos: o de individualização, resultante do menor peso das grandes identidades profissionais e coletivas na dinâmica social; e o de relativa perda de importância do trabalho, ou do efeito, sobre a existência individual e familiar, das relações de trabalho, das trajetórias profissionais, das condições, conteúdos e remuneração do trabalho. Ora, se as identidades profissionais institucionalizadas do período fordista se enfraqueceram ou mesmo se dissolveram para algumas categorias sociais (mais na indústria do que no setor terciário), e se a variabilidade das ocupações no curso de vida aumentou em razão da redução dos empregos e das carreiras "seguras" 29 , o campo de possibilidades da grande maioria das pessoas, homens ou mulheres, permanece limitado a ocupações do universo do emprego assalariado (no qual os empregadores ainda são os responsáveis pela seleção das qualificações daqueles que empregarão), e também do universo do assalariamento disfarçado de "empreendedorismo". Ademais, e ao contrário do sonho de uma civilização do lazer na sociedade pós-industrial, as diferentes e novas formas de intensificação do trabalho, ao lado da crescente insegurança socioeconômica, sobretudo dos mais jovens, acentuaram a pressão sobre o trabalho, e também os efeitos das pressões associadas ao trabalho sobre o tempo vivido fora dele. A ocupação, pois, continua tendo centralidade na vida de homens e mulheres que adquirem meios de vida vendendo sua força de trabalho.

Como já foi dito, no Brasil, a menção à categoria social "classes médias" denota, quase sempre, a classe média alta. Mas a "nova classe média" de Wright Mills era muito mais do que isso. Era também o 
imenso conjunto de ocupações surgidas com o crescimento dos serviços de apoio à produção, como transporte, armazenagem, comunicação, intermediação financeira, comércio etc.; com a multiplicação dos serviços sociais ofertados pelo Estado; com a burocratização da gestão das grandes empresas; com a ampliação da indústria cultural etc. Estas já não são a "nova classe média", mas, hoje, o que conhecemos, justamente, por classes médias, um conjunto muito heterogêneo e hierarquizado, que comporta desde trabalhadores dotados de grande autonomia de ação em seu trabalho, alto prestígio e reconhecimento social, capacidade de transferência de sua posição aos filhos ou mesmo de financiar sua ascensão social etc.; até os assalariados de escritório, cujo trabalho, subordinado, precário, rotineiro, inseguro e de baixa remuneração, se distingue apenas tenuemente do de um operário industrial, categoria, hoje, minoritária na estrutura de classes do país ${ }^{30}$.

Depois de C. Wright Mills, a participação dos serviços na atividade econômica se amplificou e se diversificou consideravelmente, e, sobretudo, o trabalho qualificado com forte componente científico ou tecnológico se tornou fator essencial da dinâmica capitalista. Neste pormenor, três mudanças estruturais importantes nos países desenvolvidos merecem ser ressaltadas. A primeira é quantitativa: houve importante crescimento das ocupações altamente (e também medianamente) qualificadas, que supõem nível de formação educacional mais elevado ${ }^{31}$.

A segunda mudança é que, no capitalismo globalizado atual, a inovação tecnológica em sentido largo tornou-se fator chave da competição intercapitalista, e o avanço tecnológico, uma vantagem competitiva que precisa ser constantemente reproduzida (ver, por exemplo, Storper, 1997). Daí o importante crescimento dos empregos diretos portadores de inovações na economia, e também o aumento de ocupações responsáveis por essas inovações no ensino superior, na pesquisa acadêmica e nos departamentos de Pesquisa e Desenvolvimento das empresas.

A terceira mudança é relativa à situação dos novos trabalhadores qualificados em sentido amplo. Contrariamente à posição tradicional das categorias superiores relacionadas direta ou indiretamente com a dominação do capital na hierarquia das empresas (e que justificaram as leituras de E. O. Wright sobre a "ambiguidade" dessas categorias, ou sua caracterização por J. Goldthorpe como "classes de serviço" ligadas à classe dirigente por uma relação de confiança), parte crescente 
das categorias qualificadas de hoje não têm mais, essencialmente, funções de direção hierárquica, nem de supervisão do trabalho de execução. Ao contrário, são elas mesmas as executoras, as produtoras diretas de bens e serviços, assimiláveis ao "trabalhador produtivo" de K. Marx. Podemos citar como exemplos os engenheiros dos escritórios de pesquisa ou de serviços de informática, os médicos hospitalares e enfermeiros, os analistas de escritório das organizações, os técnicos de laboratório, os professores e pesquisadores e tantos outros.

Logo, é essencial, hoje, dispor de medidas adequadas das posições sociais existentes, derivadas da divisão do trabalho, que permitam caracterizar as classes médias e que, ademais, sejam detalhadas o suficiente para capturar as transformações contemporâneas.

\section{Uma Proposta de Classificação das Ocupações}

Por muitos anos, parte considerável dos estudos de estratificação social no Brasil empregou a classificação elaborada por Nelson do Valle Silva em 1988, resultante de uma agregação da Classificação Brasileira de Ocupações (CBO) utilizada pelo IBGE nas pesquisas domiciliares daquela década. A nota de Silva (1988) talvez tenha sido o manuscrito mais influente dos estudos de estratificação e mobilidade social do país. Nunca publicado, mas amplamente citado, sugeriu uma agregação da CBO em 18 categorias socioprofissionais que distinguia trabalho rural e urbano, separando, no âmbito deste último, trabalho manual e trabalho não manual. Incorporou também os ramos de atividade para distinguir trabalhadores manuais dos serviços e da indústria, subdividindo esta última em indústrias modernas e tradicionais, e, no grupo dos primeiros, trabalhadores manuais de rotina (escritório), trabalhadores manuais dos serviços, domésticos etc. Identificou também os profissionais liberais, os técnicos de nível médio, os proprietários e "empresários por conta própria", entre outros. A classificação era elegante, parcimoniosa e intuitiva e, até recentemente, preferida no país.

Contudo, essa classificação nos parece pouco sensível à heterogeneidade dos setores médios da estrutura social. É verdade que identifica claramente a classe média alta (dirigentes e administradores de alto nível, e profissionais liberais), e conta com cinco categorias intermediárias (Profissionais; Funções administrativas de execução; Trabalhadores não manuais de rotina; Técnicos, artistas e supervisores do trabalho manual; Técnicos e administradores do setor primário). Mas não dis- 
tingue o emprego nos setores público e privado, por exemplo. Inclui a categoria "Empresário por conta própria sem empregado", mas não identifica a ocupação ou a qualificação profissional desse empreendedor, que pode ser um artesão ou um prestador de serviços a empresas, com consequências bem distintas em termos de oportunidades de vida.

Uma alternativa seria a popular "EGP" (Erikson e Goldthorpe, 1992), categorização proposta inicialmente por John Goldthorpe e muito usada nos estudos comparativos internacionais de mobilidade social. A versão mais detalhada distingue onze categorias. As classes médias, tal como as compreendemos aqui, estão principalmente na categoria II (Profissionais, administradores e gerentes menos graduados; Técnicos mais graduados; Gerentes em pequenos estabelecimentos industriais; Supervisores do trabalho não manual), com uma interrogação sobre a fronteira com a categoria I (Profissionais mais graduados). Podemos ainda supor que ao menos parte da categoria IIIa (Trabalhadores não-manuais de rotina de mais alto nível) pertence às classes médias, assim como uma parte da categoria $\mathrm{V}$ (Técnicos menos graduados, supervisores do trabalho manual). No total, as classes médias dispõem somente de uma categoria, com algum complemento possível em três outras $^{32}$.

Para este estudo, que faz parte de um projeto mais amplo que visa a comparar a segregação espacial, segundo as classes sociais e a raça, nas regiões metropolitanas de Paris, São Paulo e Rio de Janeiro, decidimos partir de outra categorização, as Categorias Socioprofissionais (catégories socioprofessionnelles - CS) francesas.

Essas categorias foram definidas pelo Institut National de la Statistique et des Études Économiques (INSEE), homólogo francês do IBGE, e são o produto híbrido de: (i) categorias elaboradas por estatísticos tendo, no ponto de partida, uma inspiração marxista; (ii) classificações profissionais oriundas de negociações coletivas entre patrões e empregados no pós-guerra; e (iii) de discussões com pesquisadores das ciências sociais para incluir as contribuições da sociologia, principalmente aquela inspirada por Pierre Bourdieu nos anos 1970 (cf. Desrosières e Thévenot, 1988). As CS são sistematicamente utilizadas na França tanto pela estatística pública (nos recenseamentos e nas pesquisas domiciliares), quanto pela maior parte dos pesquisadores e mesmo de um conjunto de institutos de opinião privados, o que permitiu resultados 
cumulativos importantes. Em razão de sua origem, e de sua grande difusão, as CS estão em bastante acordo com as autorrepresentações dos atores entrevistados, o que lhes garante boa confiabilidade na França.

A CS tem três níveis principais de definição arborescente: a CS "de um dígito", com seis categorias ocupacionais; a CS em "dois dígitos", com 31 categorias, sociologicamente a mais interessante; e a CS em "três dígitos", mais detalhada e com 486 denominações ocupacionais.

Para adaptar a CS aos dados brasileiros, foi preciso modificar a definição de algumas ocupações, distanciando-as das definições mais especificamente francesas. O caso mais claro é o da categoria cadre, que corresponde, na França, a um estatuto profissional diferenciado, com vantagens sociais, sistema próprio de aposentadoria etc., diferentes para os assalariados dos escalões superiores da hierarquia das empresas $^{33}$. Como não existe algo semelhante no Brasil, utilizamos a posse ou não de diploma superior como critério de hierarquização das posições superiores, que as aproximasse dos cadres. Tal redefinição mantém um bom nível de comparabilidade, e também torna a categoria próxima da Classe I da EGP ${ }^{34}$. Outras categorias também idiossincráticas são as distinções dos níveis de qualificação entre os operários, que a classificação francesa separa em qualificados e não qualificados. Essa distinção não está disponível na $\mathrm{CBO}$, por isso a substituímos pela separação entre operários dos setores formal e informal (específica do Brasil). Mais um exemplo, dentre muitos outros ${ }^{35}$ : os trabalhadores manuais por conta própria foram classificados como artesãos (CS21) ou como operários (CS6x), segundo sejam ou não contribuintes da previdência social. Tivemos também, em certos casos, que adaptar a nomenclatura da CS. Decidimos separar os trabalhadores domésticos do pessoal de serviços diretos a particulares (CS56), com os quais eles estão agrupados na França por serem uma categoria pouco numerosa, contrariamente ao Brasil.

Para isso foi preciso proceder a um árduo trabalho de construção crítica da correspondência entre CBO e CS. Dizemos "árduo" porque, se a análise dos documentos metodológicos que descrevem a $\mathrm{CS}^{36}$ e a $\mathrm{CBO}^{37}$ permite, para boa parte das ocupações no nível mais fino da CBO (de cinco dígitos, com pouco mais de 600 denominações ocupacionais), encontrar a correspondência com a CS de dois dígitos sem ambiguidade, não é este o caso para outra parte importante, na qual uma categoria da CBO corresponde a mais de uma categoria da CS de dois dígitos. Foi 
necessário construir a correspondência por meios mais complexos através do cruzamento de diferentes variáveis, de maneira tão homóloga quanto possível aos cruzamentos dos quais resulta a própria CS, ou, não sendo possível, de encontrar aproximações razoáveis. Foi preciso combinar outras informações disponíveis nos censos e nas pesquisas domiciliares brasileiras, como a posição na ocupação, o ramo de atividade, a escolaridade e até mesmo a renda, para tornar a CBO equivalente à CS.

Essa "adaptação" foi realizada pela primeira vez com os dados do Censo Demográfico de 2000 (cf. Préteceille e Cardoso, 2008). Nós a revisamos, corrigimos e refinamos para traduzir a CBO usada na Pesquisa Nacional por Amostra de Domicílios (PNAD) de 2002 a 2014, base de dados que utilizaremos aqui ${ }^{38}$.

Para a questão que nos ocupa, as classes médias, a vantagem comparativa da CS francesa, vis-à-vis as alternativas disponíveis (Silva, EGP e outras) é justamente sua grande sensibilidade aos setores médios da estratificação social.

O núcleo central das classes médias é constituído pela grande CS4, das profissões intermediárias, que comporta sete categorias:

CS42: Professores dos ensinos fundamental e médio, instrutores

CS43: Profissões intermediárias da saúde e do trabalho social

CS44: Clérigos e religiosos

CS45: Profissões intermediárias administrativas da administração pública

CS46: Profissões intermediárias administrativas e comerciais das empresas

CS47: Técnicos

CS48: Contramestres, agentes de supervisão do trabalho

Apresenta, portanto, nível de detalhe analítico consideravelmente superior às outras nomenclaturas discutidas antes. Comparando com a EGP, esse melhor nível de detalhe resulta do uso pela CS de distinções relativas ao setor de atividade e à diferença entre público e privado, que faz sentido tanto para a França quanto para o Brasil. Por sua posição na divisão do trabalho, seu nível de qualificação, de escolaridade e 
sua renda, essas categorias, que são essencialmente de assalariados (com exceção de certas profissões intermediárias da saúde, exercidas como profissões liberais) se distinguem claramente das categorias populares, caracterizadas por sua posição dominada no trabalho e na vida cotidiana, dominação marcada pela precariedade dos recursos e a insegurança das condições de existência, e pela alteridade cultural (Schwartz, 2011).

Elas se distinguem também claramente das categorias superiores, definidas por sua posição dominante na economia e nas posições de poder institucional; e se distinguem das categorias médias superiores - situadas de forma mais ambígua entre a parte inferior das classes dominantes e a parte superior das classes médias -, que correspondem ao senso comum da expressão "classe média" no Brasil (cf. Salata, 2016). Sublinhe-se que essas categorias médias, que são normalmente ignoradas nas descrições habituais das classes médias, constituíam, em 2014, $12,2 \%$ da população ocupada no país.

A fronteira entre as classes superiores e as classes médias atravessa a grande CS3, Cadres et professions intellectuelles supérieures no original francês. As mudanças na divisão do trabalho e nos estatutos profissionais que indicamos anteriormente, fazem com que boa parte dos ativos não deva ser, hoje, considerada como pertencente às classes superiores, contrariamente ao título da CS3. O caso mais evidente é o da CS34, na qual a maioria dos efetivos é constituída por professores do ensino secundário (ou médio, no Brasil). Se, na França dos anos 1970, estes podiam ser considerados como categorias superiores, em razão do seu "capital escolar" (seguindo-se a análise de Bourdieu), a degradação de seus salários, de suas condições de trabalho e de seu prestígio social os coloca hoje, sem ambiguidade, nas classes médias. Isso é ainda mais verdadeiro no Brasil, onde o estatuto relativo dessa categoria sempre foi mais baixo do que na França. Podemos agregar, também, boa parte dos professores do ensino superior (principalmente no setor privado), cujos salários e estatuto também se degradaram fortemente em termos relativos, e cuja atividade profissional, nas condições de massificação do ensino superior, não tem nada de "superior" ${ }^{\prime 39}$. Apenas uma minoria da CS34 pode de fato ser considerada como fazendo parte das classes superiores.

O mesmo arrazoado vale para a maior parte dos membros da CS35 (Profissões da informação, das artes e espetáculos). Se os jornalis- 
tas-vedetes dos meios de comunicação, os atores, escritores, pintores e músicos célebres pertencem sem dúvida às classes superiores, eles são uma pequena minoria nessa categoria. A grande maioria dos jornalistas, atores, músicos, pintores e outros trabalhadores das artes e espetáculos (cenógrafos, decoradores...) têm renda baixa e precária, malgrado o prestígio social de sua atividade. Na França, e também no Brasil, é a CS3x na qual a renda mediana é de longe a mais baixa, e mais próxima das CS4x do que das demais CS3x; e na qual a distância entre as rendas média e mediana é a maior, em razão da renda muito elevada da pequena minoria superior ${ }^{40}$.

Como já assinalado, uma parte crescente das CS37 e CS38 (engenheiros e altos cargos comerciais e administrativos das empresas) é, hoje, composta de executantes de trabalho muito qualificado, e produtores diretos com pouca ou nenhuma responsabilidade hierárquica sobre outros trabalhadores. Como distingui-los dos que pertencem claramente aos quadros da hierarquia dirigente das empresas e são, pois, indiscutivelmente membros das classes superiores? Para estabelecer uma fronteira entre as classes médias e superiores ${ }^{41}$, são necessárias informações sobre a posição hierárquica e o conteúdo do trabalho. Embora as PNADs utilizadas aqui não apresentem informação sobre a posição hierárquica, é possível, a partir da CBO detalhada, que foi por nós empregada para construir a CS, distinguir, no âmbito das CS37 e CS38, as categorias profissionais que, por sua denominação, correspondem precisamente às funções de direção das empresas ${ }^{42}$. Para este trabalho, então, retiramos das CS37 e CS38 essas ocupações de direção, deixando apenas as que pertencem claramente às classes médias superiores.

O caso da CS33 (membros das categorias superiores da função pública) é diferente. Se na França sua renda é menor do que a dos membros das CS37 e CS38, e, por isso, seu perfil é efetivamente médio (com exceção da alta função pública), no Brasil isso não acontece. Nada menos que $67,3 \%$ dos membros da CS33 estavam entre os 10\% mais ricos em 2014, segundo a PNAD. Logo, parece menos pertinente assimilá-los às classes médias.

Em 2014, o conjunto das classes médias altas assim definidas (CS34, CS35, e CS37 e CS38 não dirigentes) representava 4,1\% dos ocupados no Brasil como um todo.

Descendo um pouco mais na hierarquia social, a CS5x agrupa os assalariados que, com exceção dos prestadores de serviços a particulares e 
empregados domésticos, costumavam ser considerados como fazendo parte das classes médias baixas (como os vendedores do comércio e agentes do serviço público), ou mesmo da pequena burguesia urbana. Mas a fronteira de classe mudou e hoje isso já não faz sentido. A maior parte dessas categorias viu suas vantagens relativas vis-à-vis os operários diminuírem consideravelmente. Boa parte conheceu um efetivo processo de proletarização, seja em termos de renda, de condições de trabalho ou de precariedade da ocupação. As categorias com vantagens relativas mais marcadas, que as distinguem dos operários (Chenu, 2005; Quadros, 2007), são a CS52 e a CS54, a primeira referindo-se aos assalariados civis e agentes do serviço público e a segunda, aos trabalhadores não manuais de escritório (os white collar de Wright Mills), que podemos considerar como parte das classes médias bai$\mathrm{xas}^{43}$. As demais categorias são, hoje, indiscutivelmente populares (Schwartz, 2011). Essas classes médias baixas representavam em 2014, $8,5 \%$ dos ocupados no total do Brasil.

Se agregarmos essas classes médias baixas às classes médias altas e às classes médias médias, atingimos, então, um total de $24,8 \%$ de participação das classes médias na estrutura social do país em 2014.

Dito isso, vejamos como essa categorização se compara com a utilizada por Marcelo Neri (estratos de renda A, B, C, D, E). Em que medida a famosa "nova classe média", a classe $\mathrm{C}$, corresponde à nossa definição sociológica de classes médias?

A resposta a essa pergunta exige um esforço metodológico adicional. O agregado "classe C" de Neri (2008) denota todos os membros de $f a-$ mílias com renda total na faixa entre a mediana da distribuição de renda e o limite dos 10\% mais ricos. Nosso agregado "classes médias" denota pessoas que exercem determinada ocupação na divisão social do trabalho, e não as famílias dessas pessoas. Precisamos, então, construir famílias de classe média a partir da ocupação de seus membros.

Uma alternativa seria definir família de classe média como aquela na qual ao menos um dos membros pertença a um dos três estratos definidos acima (média alta, média ou baixa). Mas sabemos que, no Brasil, as famílias são híbridas, já que as oportunidades ocupacionais individuais não são as mesmas segundo o gênero, a idade, a raça, a escolaridade etc. Uma mesma família pode ter e frequentemente tem pessoas em diferentes ocupações, resultando em mesclas de classe que tornam difícil a atribuição unívoca do arranjo familiar a uma única classe. Com 
isso, decidimos capturar todas as combinações possíveis de classe dos membros das famílias e cruzar o resultado pelos estratos de renda sugeridos por Marcelo Neri (Tabela 1).

Tabela 1

Estrutura ocupacional do Brasil. Classes CS e estratos de M. Neri em 2014

\begin{tabular}{|c|c|c|c|c|c|}
\hline \multirow{2}{*}{ Estrutura de classe da família } & \multicolumn{4}{|c|}{ Estratos de renda Neri } & \multirow{2}{*}{ Total } \\
\hline & Classes AB & Classe C & Classe D & Classe E & \\
\hline Superior pura & 67,4 & 28,6 & 2,9 & 1,1 & 100,0 \\
\hline Superior + média & 72,0 & 25,2 & 2,2 & 0,7 & 100,0 \\
\hline Superior + média + pop. & 59,0 & 37,0 & 3,0 & 0,9 & 100,0 \\
\hline Superior + popular & 46,9 & 45,8 & 5,4 & 1,9 & 100,0 \\
\hline Média pura & 25,7 & 47,0 & 19,8 & 7,5 & 100,0 \\
\hline Média + popular & 13,7 & 61,9 & 19,8 & 4,6 & 100,0 \\
\hline Popular pura & 3,3 & 38,3 & 37,5 & 20,8 & 100,0 \\
\hline Classes rurais & 1,6 & 17,7 & 31,9 & 48,7 & 100,0 \\
\hline Todos fora da PEA/Sem informação & 8,6 & 37,0 & 20,9 & 33,5 & 100,0 \\
\hline Total & 9,9 & 40,0 & 29,4 & 20,6 & 100,0 \\
\hline \multirow{2}{*}{ Estrutura de classe da família } & \multicolumn{4}{|c|}{ Estratos de renda Neri } & \multirow{2}{*}{ Total } \\
\hline & Classes AB & Classe C & Classe D & Classe E & \\
\hline Superior pura & 7,9 & 0,8 & 0,1 & 0,1 & 1,2 \\
\hline Superior + média & 8,7 & 0,8 & 0,1 & 0,0 & 1,2 \\
\hline Superior + média + pop. & 2,3 & 0,4 & 0,0 & 0,0 & 0,4 \\
\hline Superior + popular & 3,6 & 0,9 & 0,1 & 0,1 & 0,8 \\
\hline Média pura & 31,6 & 14,4 & 8,2 & 4,5 & 12,2 \\
\hline Média + popular & 20,8 & 23,3 & 10,2 & 3,4 & 15,1 \\
\hline Popular pura & 16,2 & 46,3 & 61,8 & 48,9 & 48,4 \\
\hline Classes rurais & 2,0 & 5,6 & 13,7 & 29,8 & 12,6 \\
\hline Todos fora da PEA/Sem informação & 7,0 & 7,5 & 5,8 & 13,2 & 8,2 \\
\hline Total & 100,0 & 100,0 & 100,0 & 100,0 & 100,0 \\
\hline
\end{tabular}

Fonte: PNAD 2014. Os estratos de classe de A a E foram criados segundo a metodologia proposta por Neri (2008).

Pela coluna "Total" da parte inferior da tabela (porcentagem de coluna), vemos que pouco mais de $72 \%$ das famílias são "puras" (incluindo-se as famílias rurais), isto é, apenas um dos membros trabalha, ou os membros que trabalham pertencem à mesma classe, definindo sem ambiguidade a classe à qual devemos atribuir a família: 1,2\% são da classe superior pura, $12,2 \%$ são classe média pura, e $48,4 \%$ popular 
pura $^{44}$. Desconsiderando-se as famílias nas quais todos os membros estão fora da PEA ou desempregados ou sem informação, os demais 17,5\% de famílias são híbridos, tendo ao menos dois de seus membros em classes distintas. As famílias híbridas que incluem ao menos um membro das classes médias congregavam 16,7\% dos brasileiros em 2014 no Brasil. Somadas às famílias de classe média "pura" (12,2\%), chegava-se a quase $29 \%$ das pessoas.

Analisando agora os resultados do cruzamento dos dois modelos, na mesma Tabela 1, vê-se que quase metade das classes médias puras (47\%) está de fato na classe $\mathrm{C}$ de renda. Contudo, a segunda parte da tabela (porcentagem de coluna) mostra que essa sobreposição é bastante parcial, já que apenas uma parte minoritária da classe C $(14,4 \%)$ pertence efetivamente às classes médias puras, tal como sociologicamente definidas aqui. Se somarmos a essas as famílias híbridas "classes médias + classes populares" chega-se a quase $38 \%$ na classe C. Na verdade, mais de $46 \%$ dos membros dessa classe pertencem às classes "populares puras". Somando-se a elas as famílias médias + populares, está-se falando de quase $70 \%$ das pessoas. A classe $C$ de renda é bem mais popular do que média.

Assim, a renda que garantiu mobilidade social à classe $C$ resulta, seja do acúmulo das rendas das pessoas ocupadas na família, seja de um salário de não pobres, modesto mas superior a $\mathrm{R} \$ 2.000$ (renda mediana em 2014), ou a pouco menos de três salários mínimos daquele ano. Logo, é um abuso de linguagem caracterizá-los como "nova classe média", assimilando essas categorias populares não pobres ou menos pobres a categorias como professores, enfermeiros, profissões administrativas ou técnicas das empresas etc. Estas verdadeiras classes médias, parte das quais são efetivamente novas, de fato existem e têm um tamanho não negligenciável, como já mostramos, mas bem mais modesto do que o conjunto da "classe $C^{\text {", }}$ que congregou $45 \%$ dos brasileiros em 2014 (ver "Total" da primeira parte da tabela).

\section{EVOLUÇÃO DA ESTRUTURA OCUPACIONAL E AS CLASSES MÉDIAS}

Houve crescimento das classes médias brasileiras no período recente, como quer parte da literatura discutida antes? Em caso afirmativo, ele foi generalizado? Se a estrutura ocupacional reflete a divisão social do trabalho, devemos esperar diferenças na composição das classes sociais segundo as regiões do país. Impossibilitados, por questões de es- 
paço, de descer a detalhes regionais ou estaduais, decidimos dividir o Brasil em "metropolitano" e "não metropolitano", e distinguimos, no Brasil metropolitano, as metrópoles de São Paulo e Rio de Janeiro das demais RM. O objetivo foi unicamente dar visibilidade ao efeito da estrutura econômica sobre a estratificação social.

Neste primeiro passo utilizamos uma descrição sintética da estrutura social em oito grandes categorias: os proprietários rurais; assalariados agrícolas; a pequena burguesia urbana (comerciantes e artesãos); as classes superiores urbanas (chefes de empresas, quadros dirigentes das empresas, profissões liberais e quadros superiores da função pública); os trabalhadores pouco qualificados dos serviços e do comércio; os operários; além das três categorias médias tal como definidas acima. Entre setembro de 2002 e setembro de 2014 o Brasil gerou 21.4 milhões de novas ocupações, segundo a PNAD ${ }^{45}$. Destas, como mostra a Tabela 2, 10 milhões, ou 47\% do total, foram ocupações de classe média, sendo 4.3 milhões de classe média baixa, 2.7 milhões de classe média "média" e 3 milhões de classe média alta. Os segmentos médios saltaram de 16.9 milhões para 26.9 milhões de pessoas em 13 anos (crescimento de $59 \%$ ). Isso elevou a participação das classes médias de $21,6 \%$ para $27 \%$ do total dos ocupados.

Tabela 2

Crescimento do número de pessoas ocupadas segundo as classes sociais Brasil, 2002-2014

\begin{tabular}{l|c|c|c}
\hline Classes Sociais & $\mathbf{2 0 0 2}$ & $\mathbf{2 0 1 4}$ & $\mathbf{2 0 1 4 - 2 0 0 2}$ \\
\hline Classes superiores urbanas & 2.048 .983 & 3.482 .200 & 1.433 .217 \\
Classe média alta & 3.313 .889 & 6.356 .813 & 3.042 .924 \\
Classe média média & 9.419 .878 & 12.092 .521 & 2.672 .643 \\
Classe média baixa & 4.155 .401 & 8.420 .025 & 4.264 .624 \\
Pequena burguesia urbana & 7.371 .194 & 9.559 .218 & 2.188 .024 \\
Classes populares urbanas & 19.955 .395 & 23.870 .927 & 3.915 .532 \\
Classe operária & 15.872 .118 & 21.370 .112 & 5.497 .994 \\
Proprietários rurais & 4.233 .316 & 3.809 .663 & -423.653 \\
Trabalhadores rurais & 11.667 .831 & 10.443 .465 & -1.224 .366 \\
\hline Total & $\mathbf{7 8 . 0 3 8 . 0 0 5}$ & $\mathbf{9 9 . 4 0 4 . 9 4 4}$ & $\mathbf{2 1 . 3 6 6 . 9 3 9}$ \\
\hline
\end{tabular}

Fonte: Microdados da PNAD 2002 e 2014.

Analisemos em maior detalhe essa evolução. O Gráfico 1 mostra a evolução da estrutura de classes do país no período de 13 anos começando 
Gráfico1

Evolução da estrutura de classes em algumas RM e no Brasil não metropolitano

(2002-2014)

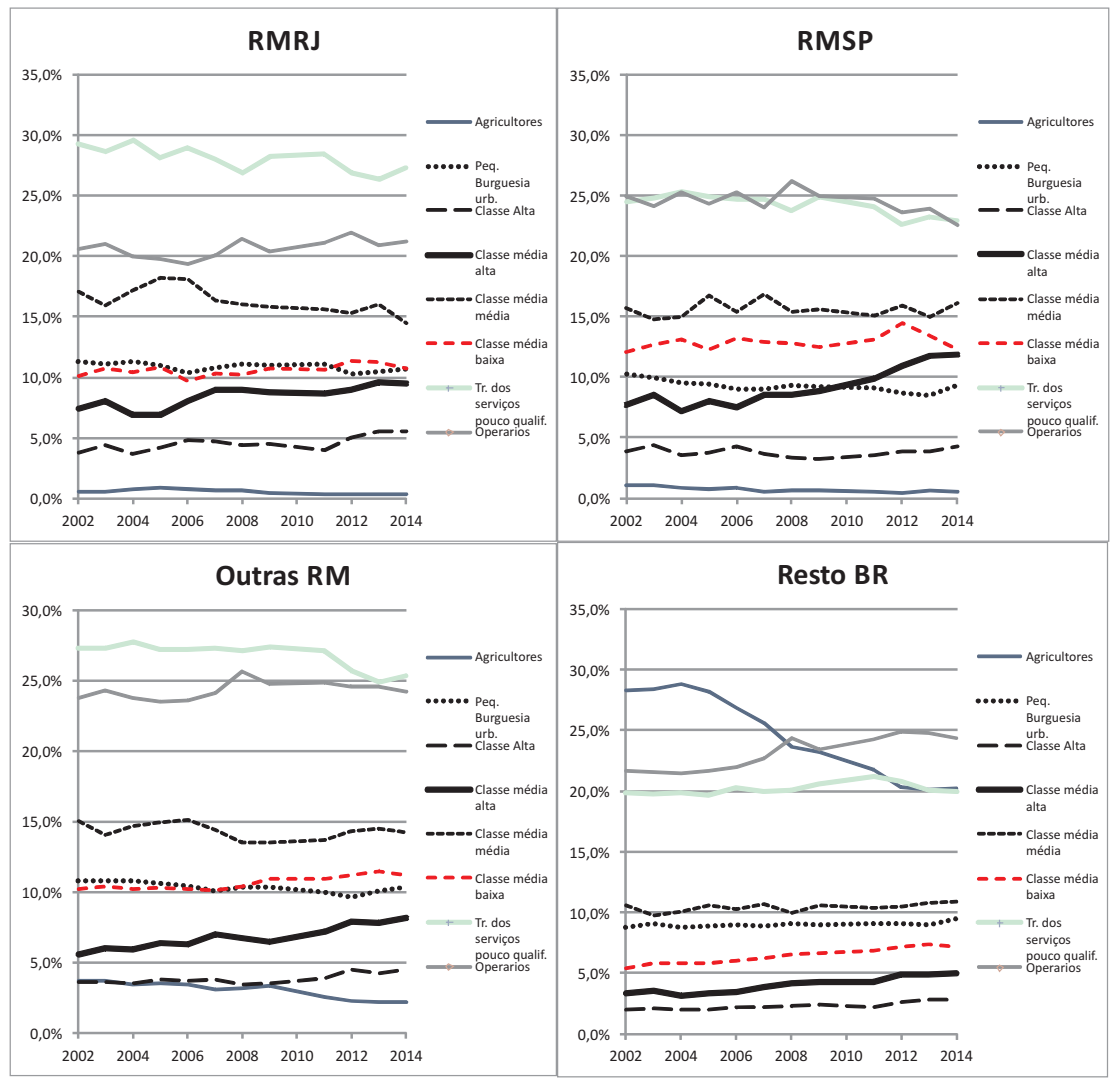

Fonte: PNAD, vários anos.

em $2002^{46}$. O objetivo é identificar os movimentos da estrutura de classe como um todo e medir o crescimento proporcional das classes médias, vis-à-vis as outras classes. Mais adiante analisaremos a evolução interna aos setores médios, usando definição mais detalhada.

Iniciemos pelo Brasil não metropolitano. De imediato, chama a atenção a redução substancial da proporção de agricultores (incluindo assalariados de seu próprio negócio e trabalhadores rurais), que caiu de pouco mais de $28 \%$ para $20 \%$ dos ocupados. Essa queda teve como contrapartida o aumento de quase três pontos percentuais na proporção de operários. Houve crescimento também significativo de dois componentes das classes médias: 1,7 ponto percentual (doravante, pp) para a classe média baixa e 1,8 pp para a classe média alta. A classe média mé- 
dia permaneceu praticamente estável ( $+0,3 \mathrm{pp})$. A classe alta e a pequena burguesia urbana cresceram ligeiramente $(+0,8$ pp e 0,7 pp respectivamente). Por fim, a categoria dos trabalhadores dos serviços pouco qualificados, que inclui as empregadas domésticas, também permaneceu estável $(+0,2 \mathrm{pp})$.

Se somarmos os três estratos médios discutidos acima, eles compunham 19,3\% dos ocupados no Brasil não metropolitano em 2002, proporção que subiu a $23 \%$ em 2014 . O interior do Brasil, portanto, conheceu crescimento significativo das classes médias no período, de 3,7 pontos percentuais, com destaque para as ocupações mais e menos qualificadas.

Na RM paulista as classes médias médias também permaneceram estáveis, mas com participação mais pronunciada, em torno de $16 \%$. Sua presença é menor na RM fluminense (14,6\%), e vem diminuindo nos últimos anos depois de atingir 18\% em meados da primeira década do século. Nas duas principais RM brasileiras, as classes médias altas conheceram importante progressão, um pouco mais marcada em São Paulo (de $7,7 \%$ a $11,8 \%$ ) do que no Rio (de 7,4\% a 9,5\%). E as classes médias baixas cresceram moderadamente, neste caso mais fortemente no Rio.

Portanto, o conjunto das classes médias cresceu significativamente na RM paulista, passando de $35,5 \%$ a $40,1 \%$ da população ocupada. No Rio, seu peso é não apenas inferior (34,7\% em 2014), como permaneceu praticamente estável, porque o aumento das classes médias altas e baixas foi praticamente anulado pela queda das classes médias médias.

Comparando esses movimentos com os ocorridos em Paris entre as mesmas categorias, São Paulo é a RM brasileira mais semelhante, e o Rio um pouco menos. Porém, em Paris o crescimento das classes médias altas e médias foi mais marcado. A principal diferença é que, em Paris, as classes médias baixas diminuíram de maneira substancial, em razão do impacto da informatização nas ocupações menos qualificadas de escritório ${ }^{47}$.

Outra diferença importante em relação a Paris é a presença elevada de operários - quase 25\% em São Paulo, em ligeira diminuição, e mais de $20 \%$ no Rio, em ligeiro aumento - ao passo que na metrópole francesa essas categorias caíram fortemente, atingindo não mais do que $13 \%$ em 2010. Nota-se também o peso bem mais pronunciado do que em $\mathrm{Pa}-$ 
ris da pequena burguesia urbana, que, mesmo em recuo moderado, chegava a $10 \%$ dos ocupados contra menos de $5 \%$ em Paris.

Nas demais regiões metropolitanas, a presença das classes médias é menor, mas conheceu crescimento significativo, aproximando-se da distribuição do Rio de Janeiro. As classes médias médias têm peso apenas levemente inferior ao do Rio, estável em torno de $14 \%$. As classes médias baixas têm peso e crescimento semelhantes aos do Rio. As classes médias altas são, em termos comparativos, as que apresentam menor participação relativa, mas também vêm crescendo (2,6 pp). A presença dos operários é elevada, perto de $25 \%$, como em São Paulo, e em leve crescimento, como no Rio. Por fim, os trabalhadores dos serviços pouco qualificados têm importância considerável, mas em queda, tal como no Rio e em São Paulo.

Voltando à comparação com o Brasil não metropolitano, vê-se que, embora a presença das classes médias não seja negligenciável, e tenha crescido (3,7 pp, como vimos), sua participação na estrutura de classes é bem menor do que nas metrópoles. A cifra $(23,1 \%)$ é um pouco mais da metade da encontrada em São Paulo e de dois terços das proporções encontradas no Rio e nas outras RM. Logo, é no Brasil metropolitano, e particularmente em São Paulo, que as classes médias se tornaram um estrato social relevante. Mas seu peso, ainda assim, é menor do que o das classes populares (35\% contra $49 \%$ no Rio e $40 \%$ contra $47 \%$ em São Paulo).

\section{MUDANÇAS NO INTERIOR DAS CAMADAS MÉDIAS}

Se a distinção entre os três grandes estratos médios já mostra diferenças notáveis em termos de tendências de evolução, tomar em conta as CS mais detalhadas trará novos elementos à nossa discussão.

Analisando a variação no interior das classes médias superiores, que apresentaram crescimento expressivo no período, descobre-se que um grupo se manteve relativamente constante: os profissionais da informação, das artes e espetáculos Sua participação aumentou levemente no Brasil não metropolitano, mas a partir de um percentual muito baixo $(0,6 \%$, atingindo $0,9 \%$ em 2014), de sorte que a variação pode ser fruto de ruído amostral.

O crescimento mais significativo, nos três espaços geográficos metropolitanos e muito particularmente na RM paulista, ocorreu entre os 
profissionais administrativos e comerciais das empresas (CS37), e entre engenheiros e técnicos de nível superior das empresas (CS38). Lembre-se que, na presente análise das classes médias, retivemos apenas os membros das CS37 e 38 que não ocupam posições dirigentes nas empresas. A esse respeito, o caso da CS37 - profissionais administrativos e comerciais das empresas - é particularmente marcante: no início dos anos 2000, a parte da CS37 pertencente às classes médias era muito pequena $(0,2 \%$ dos ocupados ou menos), o que quer dizer que a maior parte pertencia às classes superiores ${ }^{48}$; mas o crescimento entre $2002 \mathrm{e}$ 2014 é considerável, o que é convergente com a discussão teórica que propusemos na primeira parte deste estudo sobre a transformação do estatuto de boa parte dessas categorias que deixaram as camadas hierárquicas da classe dominante assimiláveis às classes superiores para se tornarem produtores diretos de bens e serviços, sem papel de comando.

Além dessa transformação estrutural ligada às mudanças na divisão internacional do trabalho, devido ao peso crescente das atividades econômicas com forte presença de trabalho intelectual altamente qualificado, há no caso brasileiro elementos conjunturais importantes, relacionados com o que vem mostrando a literatura sobre a reviravolta nos métodos gerenciais nos anos 2000. Ao contrário do que ocorreu na década de 1990, assiste-se a processos de "desterceirização" de atividades e de recontratação de gerentes e técnicos de nível superior, seja para adaptação das tecnologias importadas nos processos de reestruturação empresarial, seja para a garantia da qualidade e redução de $r e-$ calls, seja para reduzir os conflitos na gestão de pessoal nos processos de recontratação de terceirizados (melhor governança corporativa), ou seja, ainda, para reduzir custos de produçãa ${ }^{49}$. Vale salientar também a presença bem mais acentuada em São Paulo da CS37, que corresponde, sem dúvida, à concentração das funções de comando da economia (sedes ou matrizes das companhias, finanças, serviços avançados de apoio às empresas), segundo o modelo da cidade global.

Também foi importante o crescimento dos professores e profissionais da atividade científica (CS34), que reflete, de um lado, a constante expansão do ensino médio nas últimas décadas, e, de outro, a expansão do ensino superior no país durante os governos do PT, não apenas nas universidades públicas (que, no caso das federais, tiveram um aumento de $54 \%$ entre 2002 e 2013), mas também nas privadas (aumento de $45 \%)^{50}$. Ao mesmo tempo, as atividades de pós-graduação e pesquisa 
Gráfico 2

Variação na composição das classes médias superiores segundo regiões selecionadas: Brasil, $2002-2014$

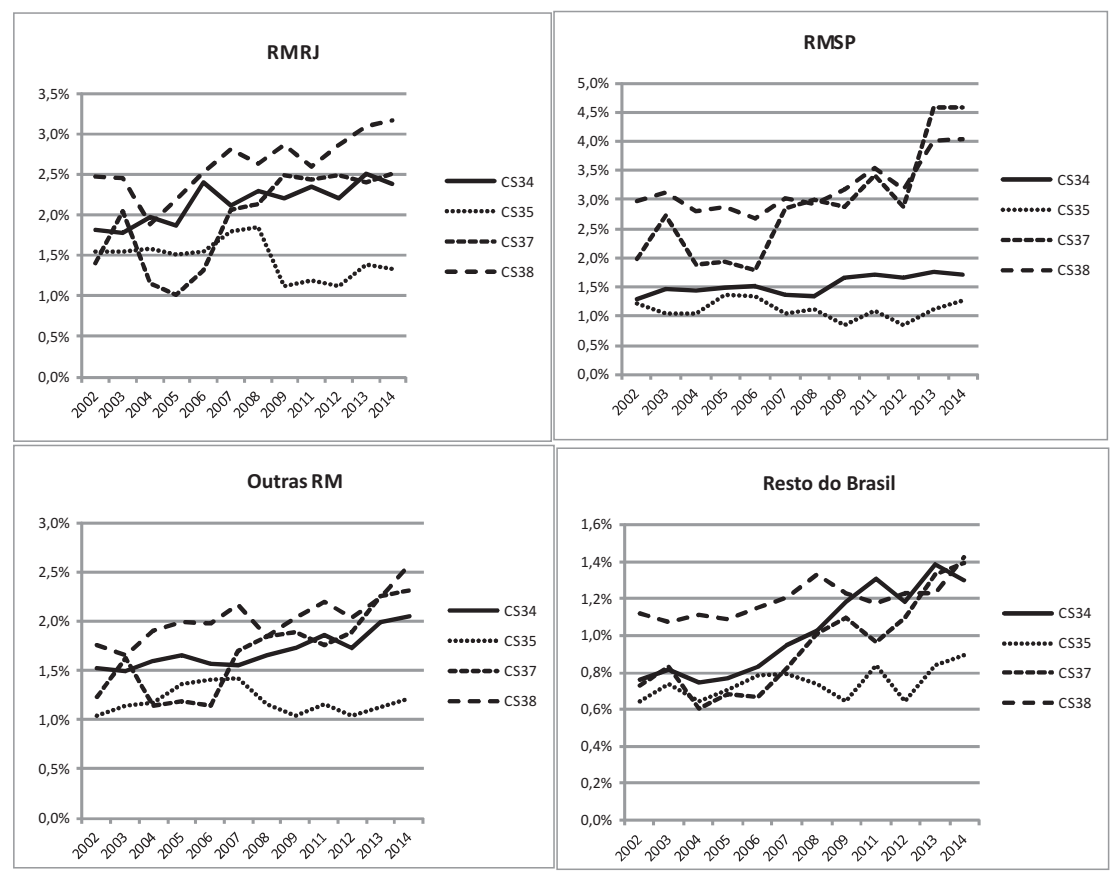

Fonte: PNAD, vários anos.

CS34: Professores, profissionais da atividade científica; CS35: Profissões da informação, das artes e espetáculos

mais que dobraram de tamanho no período, com o crescimento do número de programas de mestrado e doutorado nos mais diversos setores da atividade acadêmica ${ }^{51}$. Importante notar, a respeito, que o crescimento desse segmento das classes médias foi significativo inclusive no Brasil não metropolitano e nas metrópoles fora do eixo Rio-São Paulo, uma vez mais expressando o processo de interiorização do ensino universitário estimulado pelas administrações petistas.

A outra categoria média superior, dos profissionais da informação, das artes e dos espetáculos (CS35), como já mencionamos, permaneceu estável (casos de São Paulo, das outras RM e do interior do Brasil) ou em leve recuo (caso do Rio de Janeiro). Esse resultado contrasta com o que vem ocorrendo nas grandes metrópoles do mundo capitalista mais desenvolvido, onde essa categoria está em franco crescimento, estando associada à expansão das assim chamadas "indústrias criativas" e par- 
ticipando centralmente da dinâmica do que alguns vêm denominando "cidades criativas" (Florida, 2005).

A imagem de estabilidade, no nível agregado, das posições intermediárias das classes médias esconde algumas mudanças no espaço social interno a esses estratos. A categoria média média com maior peso nas metrópoles (Profissões intermediárias, administrativas e comerciais das empresas - CS46) teve queda moderada em São Paulo, onde tem a presença mais acentuada, e queda substancial no Rio e nas outras metrópoles. Há, aqui, um contraste interessante com o caso de Paris, onde a CS46 é também a que tem o peso mais importante, mas teve crescimento pronunciado. Esse contraste abre uma dupla questão de pesquisa, pois o resultado de Paris se opõe aos modelos dominantes da dualização ligada à globalização e à redução dos níveis hierárquicos nas grandes empresas, e o resultado para o Rio não pode ser explicado senão por uma grande adequação do modelo da cidade global como cidade dual. E no Brasil não metropolitano essa categoria tem participação diminuta.

As outras duas profissões intermediárias ligadas às empresas são os técnicos (CS47) e os contramestres (CS48). Os técnicos, cuja presença mais pronunciada é também em São Paulo, estão em progressão em toda parte, embora mais intensamente na metrópole paulista, um pouco menos no Rio e muito pouco nas demais regiões. Já os contramestres estão, inversamente, em tendência de queda no Brasil inteiro, em linha com o recuo do emprego industrial clássico (de que os contramestres são uma figura típica) e o crescimento do emprego industrial ou de serviços de tipo tecnológico, que implica em maior participação de técnicos e tecnólogos.

Ainda neste âmbito (ocupações do mundo empresarial), destacam-se os empregados administrativos das empresas (CS54), que estamos considerando como pertencentes às classes médias baixas, juntamente com os servidores públicos menos graduados (CS52). O gráfico mostra dois resultados claros: uma forte presença da CS54 nas metrópoles, menor no Brasil não metropolitano (menos da metade); e seu crescimento em todas as regiões. Esse resultado também contrasta com o encontrado nas grandes metrópoles do mundo capitalista rico, como é o caso de Paris, onde essa categoria está em queda há pelo menos trinta anos em razão do desenvolvimento das tecnologias de informação, que suprimiram várias ocupações de execução nos escritórios. Uma 
Gráfico 3

Variação da composição das classes médias médias

e baixas segundo regiões selecionadas

Brasil, 2002-2014

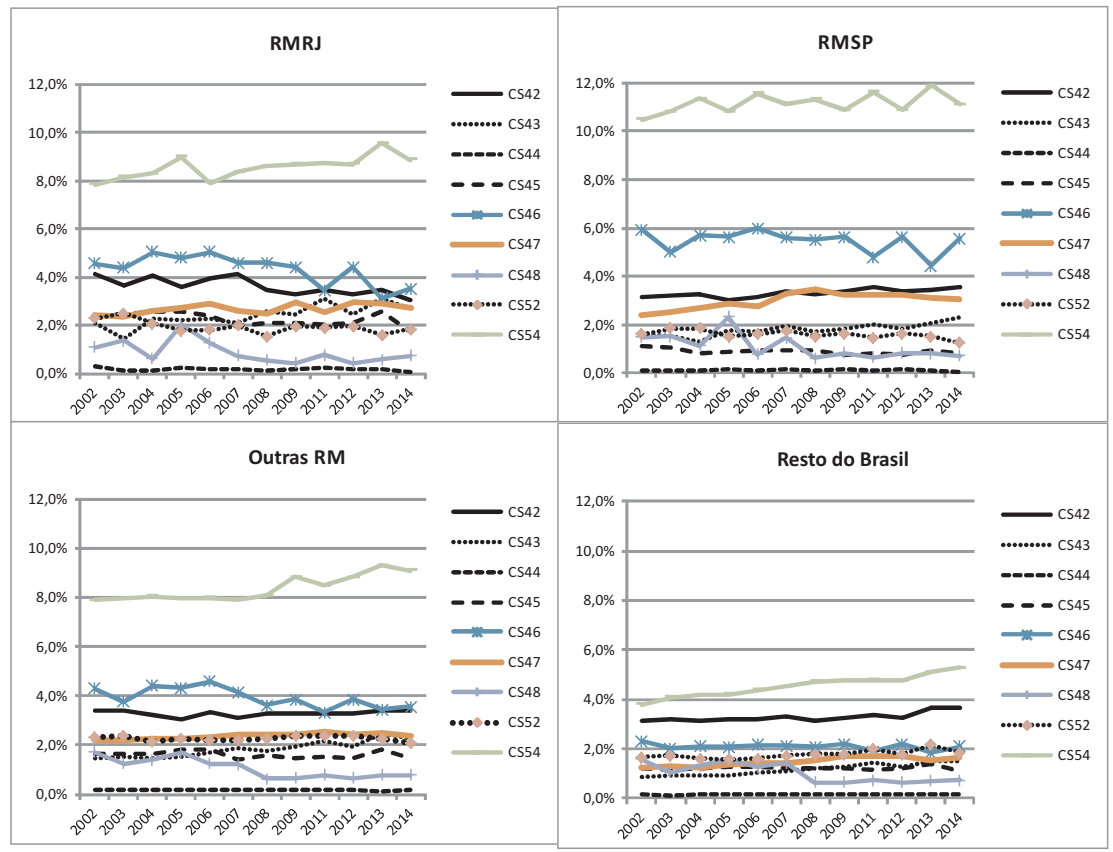

Fonte: PNAD, vários anos

CS42: Professores ens. fundamental e médio, instrutores; CS43: Profissões intermediárias da saúde e do trabalho social; CS44: Clérigos e religiosos; CS45: Profissões intermediárias da adm. pública; CS46: idem, das empresas; CS47: Técnicos (exceto técnicos terciários); CS48: Contramestres, agentes de supervisão do trabalho; CS52: Assalariados civis e agentes de serviço da adm. Pública; CS54: Empregados administrativos de empresas

vez mais é digna de nota a presença mais intensa dessa categoria em São Paulo, que aparece, também neste caso, como metrópole mais claramente empresarial. Nesta metrópole e no Rio, os servidores públicos estão em queda, enquanto crescem nas outras metrópoles e no interior do Brasil, embora em proporção diminuta.

A segunda profissão intermediária mais numerosa depois da CS46 é a dos instrutores e assemelhados (CS42). Essa categoria compreende principalmente os assalariados do setor público, malgrado o peso não negligenciável do ensino privado no Brasil. Ao contrário das categorias anteriores, o peso da CS42 é aproximadamente o mesmo nas metrópoles e no resto do país, estando em ligeiro crescimento em São 
Paulo e no Brasil não metropolitano, e estável nas outras metrópoles. O Rio se distingue tanto por ter um nível mais elevado no início do período (quase $25 \%$ a mais), quanto pela queda expressiva ao longo dos anos, que terminou por aproximá-la das outras metrópoles.

A categoria seguinte é a das profissões intermediárias da saúde e do trabalho social (CS43), que também inclui os setores público e privado. Compreendendo $2 \%$ ou menos dos ocupados, cresceu em toda parte, sendo que o crescimento foi proporcionalmente maior onde sua participação era menor no início: cresceu $28 \%$ no Rio, $44 \%$ em São Paulo, $53 \%$ nas outras RM e $66 \%$ no Brasil não metropolitano. Na média do país, o crescimento foi de $64 \%$, embora a partir de um patamar inicial muito baixo ( $1,1 \%$ dos ocupados).

O crescimento das CS42 e 43 parece refletir o aumento do investimento público em saúde e educação na última década, que, tudo indica, foi generalizado no país (Cardoso, 2013). Mas foi um crescimento tímido, de 0,4 pontos percentuais no caso da CS42 e de 0,7 pp no caso da CS43, tomando-se o Brasil como um todo.

A última categoria média a considerar é a das profissões intermediárias administrativas da função pública (CS45). Aqui também encontramos uma hierarquia de sua participação, mais forte nas metrópoles e mais branda no Brasil não metropolitano. E embora seja bastante estável no tempo, está em ligeira queda no Rio de Janeiro. Chama a atenção o caso paulista, no qual os administradores públicos médios têm metade da participação encontrada no Rio ou mesmo nas outras metrópoles, estando próxima à do resto do Brasil. O peso mais pronunciado no Rio está, provavelmente, associado à sobrevivência de organismos públicos federais (como a Fiocruz e o IBGE), além da densa rede de universidades públicas da metrópole fluminense.

\section{CONCLUSÕES}

No debate brasileiro sobre as classes médias, como nos debates internacionais, boa parte das diferenças nos resultados empíricos dos estudos decorre de posições teóricas diversas e dos modos, muitas vezes implícitos, de se definir classes médias. Aqui, ao nos inscrevermos na tradição sociológica aberta por C. Wright Mills, optamos por uma definição centrada na ocupação, que permite identificar as posições sociais intermediárias que não são nem as posições econômica e hierarquicamente dominantes das classes superiores, nem as posições de exe- 
cução dominadas das classes populares. Demos trato empírico a essa definição, por meio da adaptação ao caso brasileiro das categorias socioprofissionais francesas, categorização bastante detalhada para as classes médias, o que permitiu ao mesmo tempo apreender melhor seus diferentes componentes e traçar com maior precisão os limites entre elas e as categorias superiores e populares.

Nessa perspectiva, as classes médias têm presença significativa e crescente no Brasil. Em 2014 sua participação na estrutura de classes era de $27,1 \%$, depois de um crescimento de $15,6 \%$ no curso dos treze anos cobertos por nossa investigação (2002-2014).

Essas classes médias definidas pelas ocupações intermediárias são duas ou três vezes mais numerosas do que a "classe média" tradicionalmente reconhecida e que é, muitas vezes, um eufemismo para designar a parte inferior das classes superiores ${ }^{52}$. Vale notar também a invisibilidade sociológica daquelas classes médias, por oposição à grande visibilidade dessa "classe média" tradicional.

Por outro lado, elas são bem menos numerosas do que a "nova classe média" recentemente descoberta pelos economistas do consumo e incensada pelos governos e organismos internacionais, como o FMI e o Banco Mundial, como prova do sucesso dos novos "países emergentes". Não é para menos: a definição da "nova classe média" é particularmente pouco seletiva. Se ficarmos com aquela proposta por M. Neri (a classe C), a maioria $(50,6 \%)$ vive em famílias das classes médias "puras", tal como as definimos; mas estas constituem menos de um quinto da classe $\mathrm{C}$, que tem a maioria de seus membros nas famílias de classes populares "puras" ou em famílias mistas de classes médias + populares. E há muito se sabe que um operário que deixa de ser pobre, nem por isso deixa de ser operário para se tornar um membro da classe média.

Essas verdadeiras classes médias, boa parte das quais é mesmo nova, no sentido de que as ocupações que as definem têm uma importância nova na ordem social, são novas, ademais, pelo fato de que, para muitos membros das classes populares, elas abriram oportunidades de mobilidade social ascendente, intra e, sobretudo, intergeracional (Ribeiro, 2014). Para essas pessoas e suas famílias, o acesso às classes médias representa uma transformação positiva notável de suas condições de vida e de suas oportunidades. Parte da literatura nega a importância dessa transformação ao afirmar que a precarização que atinge também as classes médias anularia tais vantagens e destruiria as clas- 
ses médias por sua proletarização. Sem subestimar a fragilidade dessas novas posições sociais, o equívoco sociológico de tal avaliação decorre da comparação do estatuto dessas novas classes médias com o lugar privilegiado da "classe média" tradicional, e não com as condições sociais das categorias populares, que também vêm se transformando.

Se essas classes médias cresceram no conjunto do Brasil, é nas grandes metrópoles, e particularmente nas duas mais importantes, Rio de Janeiro e São Paulo, que elas têm presença mais saliente. Ainda assim, há diferenças notáveis entre São Paulo, onde seu peso é mais forte e cresceu substancialmente de 2002 a 2014, e Rio de Janeiro, onde sua presença é um pouco menor e permaneceu estável no mesmo período.

O estudo da evolução das diferentes categorias detalhadas que compõem as classes médias permitiu mostrar a diversidade das mudanças no tempo, e as diferenças entre as regiões quanto à sua estrutura e sua dinâmica. $\mathrm{O}$ crescimento mais acentuado foi o das categorias médias superiores das empresas, movimento particularmente intenso em São Paulo, onde essas categorias estão também mais presentes. As categorias médias inferiores ligadas às empresas (empregados de escritório) e os técnicos também cresceram, embora mais moderadamente.

Observou-se também um crescimento muito forte e geral das profissões ligadas ao ensino superior, médio e fundamental, e também à pesquisa. Essas ocupações estão principalmente, mas não unicamente, no setor público. Houve também crescimento importante das profissões intermediárias da saúde e do trabalho social, elas também ligadas em grande parte, mas não unicamente, ao setor público. Esses dois conjuntos de categorias são bem mais presentes no Rio de Janeiro do que em São Paulo ou nas outras metrópoles, ainda que seu crescimento tenha sido modesto e em alguns casos houve mesmo uma redução.

Essa diversidade relativa das estruturas e dinâmicas das classes médias entre as metrópoles exige princípios explicativos igualmente diversos. Os efeitos da difusão internacional dos modelos produtivos com forte componente de trabalho muito qualificado na indústria e nos serviços são evidentes, sobretudo, no caso de São Paulo. Mas a presença importante das categorias médias qualificadas das empresas, e o crescimento do emprego de escritório, constituem desvios importantes em relação ao que se observa nas grandes metrópoles do mundo capitalista mais desenvolvido. Isso pode estar relacionado com a nature- 
za das novas ocupações emergentes no mundo privado, já que boa parte dos novos empregos formais criados nos últimos anos ocorreu nas pequenas e médias empresas, sendo ao mesmo tempo instáveis e de baixa remuneração. Assim, segundo dados da Relação Anual de Informações Sociais (RAIS), dos 20,9 milhões de empregos formais criados entre 2002 e 2014, 5,4 milhões (ou quase 26\%) foram em empresas com menos de 20 ocupados, e $80 \%$ deles em empresas do comércio e dos serviços. Se incluirmos empresas com menos de 100 empregados, temos quase metade dos empregos criados, $78 \%$ dos quais nos mesmos dois setores ${ }^{53}$. Isso quer dizer que a crise econômica iniciada em 2015, que se aprofundou em 2016 e 2017, levando o desemprego a quase $14 \%$, provavelmente solapou parte significativa desses empregos. Será importante ver, a partir dos dados das próximas PNADs, quais foram as classes mais afetadas pelo desemprego, para verificar se o crescimento significativo das classes médias até 2014 foi confirmado ou anulado.

Como em Paris, e contrastando com o que vem sendo observado em Londres ou Nova York, tanto as categorias médias superiores quanto as ligadas ao ensino, à pesquisa, à saúde e aos serviços sociais conheceram um crescimento significativo, em boa parte ligado ao crescimento do setor público. Pode-se perceber um efeito das políticas públicas dos governos federal, estaduais e municipais, que ampliaram esses serviços públicos num período de crescimento dos recursos orçamentários destinados a eles. Há também um efeito da melhoria do nível de vida das classes populares, que resultou em novas e crescentes demandas por parte delas de serviços de educação e saúde privados, demanda que gerou emprego qualificado para as categorias médias nesses serviços. E há diferenças segundo as metrópoles: pudemos notar que, na evolução das categorias médias ligadas aos serviços sociais, o peso do setor privado é sensivelmente mais forte no Rio do que nas outras regiões, incluindo o Brasil não metropolitano, e cresceu entre 2002 e 2014. Isso estará refletindo, supõe-se, o menor investimento dos entes federativos na metrópole fluminense, que possibilitou o avanço do mercado nesses setores essenciais para o bem estar da população ${ }^{54}$.

A diversidade das categorias e de suas dinâmicas nos obriga a utilizar o plural ao falar das classes médias. Para além da diversidade dos níveis de diploma e de qualificação, dos setores de atividade (indústria, serviços às empresas, serviços a particulares), dos setores público ou privado, apreendidos pelas categorias socioprofissionais, seria importante se pudéssemos ter informação sobre as trajetórias de mobilidade 
social, ascendente ou descendente, e sobre a transmissão patrimonial, fatores de heterogeneidade das classes médias sublinhados de longa data.

Passar do plural ao singular exigiria pôr em evidência um eventual processo de homogeneização e de emergência de uma consciência coletiva - classe em si e para si - inteiramente hipotética nos dias de hoje. É verdade que parte dos movimentos sociais que emergiram no Brasil nos últimos anos unificou estratos das classes médias contra o projeto político que ocupou o poder central a partir de 2003. O efeito demonstração das massas nas ruas vestindo-se com as cores da bandeira nacional e os processos de identificação e projeção que a cobertura midiática permite naqueles que, não estando nas ruas, se sentem representados pelos manifestantes, podem produzir a unificação política e o sentimento de pertencimento de todos a uma mesma classe. Mas tal unificação tende a ser efêmera, já que, se todos gritaram contra um partido político e suas lideranças, não há nem nunca houve consenso sobre que caminho seguir depois de uma eventual vitória do movimento. Identidades coletivas são sempre construídas contra e na luta com adversários que, em sua ação, são capazes de unificar a ação coletiva. Retirado de cena o inimigo comum, as classes médias que foram às ruas dificilmente marcharão juntas na construção do futuro.

(Recebido para publicação em 11/5/2016) (Reapresentado em 14/3/2017) (Aprovado para publicação em 19/7/2017) 


\section{NOTAS}

1. Exemplos desse tipo de abordagem (em meio a uma já volumosa literatura) são Milanovic e Yitzhaki (2002); Bussolo et al. (2008); Franco et al. (2010); Kharas (2010); Bussolo et al. (2014); Wietzke e Sumner (2014); Clément e Rougier (2015).

2. Ver Bussolo et al. (2014) e a boa revisão da literatura de Wietzk e Sumner (2014), entre muitos exemplos salientes na literatura internacional. A relação da classe média com a sustentabilidade da democracia, contra a revolta resultante do excesso de desigualdade, está em Aristóteles (2008: 169-170). Está também em Tocqueville, que vê na classe média o esteio da democracia norte-americana. C. Wright Mills, discutido mais adiante, também trata do tema.

3. Caso de Clément e Rougier (2015). Uma crítica é Salama (2014).

4. Para o caso da África, uma boa revisão bibliográfica nesta perspectiva é Darbon (2012).

5. Que se tornou tema específico de investigação na tradição de estudos de mobilidade social.

6. Tema central nos estudos sobre as classes médias latino-americanas, como em Franco et al. (2010) e Birdsall et al. (2000), neste último caso analisando também outros países emergentes.

7. Tema de grande saliência nas literaturas francesa e americana, como em Chauvel (2006), Maurin (2009), Peugny (2009), Sullivan et al. (2001), Pressman (2007), e também no Brasil, como em Grün (1998) e Diniz (1998). Diniz contesta a tese da proletarização dos profissionais de classe média, mas o importante é que ela se coloca a questão clássica proposta por Mills. Interessante bestseller dos anos 1980 sobre o tema nos EUA é Ehrenreich (1994).

8. Como em Boudon (1981) ou Bourdieu e Passeron (1994).

9. Tema central em Bourdieu (1979).

10. Como na vasta literatura sobre estrutura de classes e mobilidade social, com exemplos expoentes em Erickson y Golthorpe (1992) e Wright (1985), e no Brasil, Pastore e Silva (2000), Scalon (1999), Ribeiro (2009), Santos (2002), dentre muitos outros.

11. Como no importante artigo de Eder (2001) e nos estudos recentes sobre a primavera árabe e os movimentos de 2013 no Brasil, de que são exemplos Vainer et al. (2013) e Castells (2013).

12. Ver também o igualmente clássico Dahrendorf (1962).

13. Ver notas 6 e 7, acima, e Bosc (2008) para uma apresentação dos debates e sua evolução, centrado no caso francês.

14. Relação que já havia interessado intelectuais no pré-1964. Souza e Lamounier (2010) garimpam o trabalho de San Tiago Dantas (sobre Rui Barbosa como herói da nascente classe média da aurora do século XX) e os Cadernos do Nosso Tempo, editado pelo grupo que mais tarde constituiria o ISEB. Para este grupo, a classe média era dotada de um falso moralismo anticorrupção que impedia a real compreensão dos problemas nacionais. Um editorial dos Cadernos com esse teor foi transcrito em Schwartzman (1981).

15. Na mesma linha, Bonelli (1989) se dedica ao estudo dos impactos da recessão do início da década de 1980 sobre a nova classe média surgida no Milagre. 
16. O levantamento cobre o período 1963-1994, mas nós o recortamos, no interesse deste estudo. Entre 1963 e 1979 foram produzidos 28 trabalhos, a maioria teses, dissertações e textos para discussão ou de pequena circulação.

17. Um importante estudo ausente do levantamento é Prandi (1982), pioneiro na identificação do processo de proletarização dos profissionais liberais, sobretudo médicos e engenheiros.

18. A literatura sobre isso é extensa no Brasil, mas textos expoentes são Fleury (1990), Grün (1994 e 1999), e Gitahy (1994), dentre outros.

19. Exemplo disso é o dossiê sobre profissões e classes médias publicado na revista Tempo Social em maio de 1998, com os importantes artigos de Maria Ligia Barbosa (1998), Roberto Grün (1998) e Marli Diniz (1998). Ver também Grün (1996).

20. Gostaríamos de destacar, entre os muitos trabalhos críticos, a boa coletânea organizada por Bartelt (2013) e, em menor medida (tendo em vista seu caráter fortemente ideológico), o estudo de Jessé Souza (2010). Críticas menos consistentes sociologicamente, mas não menos devastadoras, são Pochmann (2012 e 2014). Estudo que leva adiante a proposta de Neri do ponto de vista das políticas públicas é Barros et al. (2011).

21. Segundo a Relação Anual de Informações Sociais (RAIS), havia 49.6 milhões de ocupados no setor formal da economia em dezembro/2014, contra $29.5 \mathrm{em} \mathrm{dez/2003.}$ (Informação tabulada diretamente dos microdados para este artigo, em http:/ / bi.mte.gov.br/scripts10/dardoweb.cgi, acessado em fevereiro de 2016).

22. Segundo a mesma RAIS, o rendimento médio real do setor formal em 2014 foi $35,1 \%$ maior do que o de 2003 (inf. tabulada diretamente dos microdados para este artigo). E o salário real médio foi bem superior ao salário mínimo nas duas pontas: $\mathrm{R} \$ 1.708 \mathrm{e}$ $\mathrm{R} \$ 2.308$ respectivamente.

23. Fonte: IPEADATA.

24. Fonte: PNAD 2014 (microdados tabulados para este artigo).

25. O rendimento médio real de um trabalhador por conta própria foi de $\mathrm{R} \$ 992,5 \mathrm{em}$ 2003, e aumentou para $\mathrm{R} \$ 1.505,2$ em 2014, crescimento de 51,7\% (valores deflacionados pelo IPCA).

26. A massa salarial da indústria cresceu $43 \%$ em termos reais entre janeiro de 2003 e janeiro de 2015, segundo a Confederação Nacional da Indústria (CNI). O emprego industrial cresceu 22,9\% no mesmo período, segundo a mesma fonte. Dados disponíveis em http://www6.sistemaindustria.org.br/gpc/externo/estatisticaAcesso SistemaExterno.faces (acessado em fevereiro de 2016).

27. Segundo a PNAD 2014, 7,9\% dos/as brasileiros/as participavam de algum tipo de programa de transferência direta de renda.

28. Na verdade, Neri (2008) define as classes de renda familiar com base na renda familiar total, enquanto a metodologia consagrada, por exemplo, pelo Banco Mundial, trabalha com a renda familiar per capita. Ver Milanovic e Shlomo (2002).

29. Vale notar que o discurso sobre a estabilidade fordista foi uma construção retrospectiva sobredimensionada, que teve validade por um período bastante curto.

30. Na verdade, o operariado industrial sempre teve participação diminuta na estrutural social brasileira. No pico do período de industrialização (1980), 16\% dos ocupados eram operários industriais (se incluirmos a construção civil atingíamos 25\%), e a partir daí a proporção caiu constantemente até 2010 , chegando a $11 \%$. Desde então vem crescendo lentamente, tendo chegado a $12,3 \%$ em 2014 (21,5\% se incluirmos a 
construção civil). Fonte dos dados: IBGE (2003), para o dado de 1980, e tabulações do Censo de 2010 e da PNAD 2014 para este artigo.

31. Esse movimento invalida a tese da dualização da estrutura social, frequentemente enunciada como efeito da globalização. Ver, por exemplo, Sassen (1991) como exemplo de contundente enunciado da tese da dualização e do desaparecimento das classes médias; e Préteceille $(1995,2006)$ ou Hamnett $(1994,2003)$, como demonstração empírica inversa, isto é, do crescimento das classes médias.

32. Ribeiro (2014: 186) afirma que, usando esse esquema de classes, "não há uma maneira simples e incontroversa de definir a classe média". A baixa sensibilidade dessa classificação aos setores médios ficou clara, ainda, no estudo de Scalon e Salata (2012). Usando uma EGP reduzida a 6 categorias (por meio do agrupamento de algumas das 11 originais), o estudo conclui que não houve mudança substancial na estrutura de classes no Brasil entre 2002 e 2009, nem aumento da classe média. Usando uma classificação mais sofisticada, mostraremos que as classes médias cresceram de forma não negligenciável. Uma boa avaliação empírica da EGP para o caso brasileiro é Carvalhaes (2015).

33. Ver a análise sociológica magistral de Luc Boltanski (1982).

34. Nessa redefinição, a CS3 e próxima aos higher grade professional, mas a categoria I da EGP agrega a esses os large proprietors que são distinguidos na CS, principalmente na CS23.

35. Os interessados na sintaxe comentada de construção das classes a partir da CBO e da CS podem solicitá-la aos autores.

36. Guia das profissões e categorias sociais, disponível no site do l'INSEE, http://www.insee.fr/fr/methodes/nomenclatures/pcsese/pcsese2003/doc/Guide_PCS-2003.pdf (acessado em março de 2016).

37. A CBO pode ser encontrada em http://www.mtecbo.gov.br/cbosite/pages/downloads.jsf (acessado em março de 2016).

38. Esse complexo trabalho foi possível em razão da abertura ao público das bases de dados do IBGE, tanto os Censos quanto as PNAD, que podem ser baixados da página web do Instituto. A primeira tentativa de tradução da CBO na CS, ocorrida nos anos 1990 (cf. Préteceille e Ribeiro, 1999), foi muito menos satisfatória, em razão de escolhas metodológicas hoje discutíveis, e da necessidade de realizar essa tradução por um técnico do IBGE - os pesquisadores não tiveram acesso direto aos dados. Retrospectivamente, tendo passado pela experiência da complexidade das escolhas metodológicas necessárias para realizar essa tradução, e da necessidade de um conhecimento bastante fino da CBO, mas também da CS em sua versão mais detalhada, temos sérias dúvidas sobre a robustez dos dados produzidos anteriormente.

39. É verdade que a carreira docente nas universidades federais foi fortemente valorizada nos governos do PT, mas não a ponto de lançar os professores ao topo da estrutura de classes. Eles continuam membros das classes médias, agora superiores.

40. Os dados que sustentam essas afirmações foram tabulados diretamente da PNAD 2014 para este artigo.

41. Fronteira fluida, pois algumas pessoas podem ter uma função parcial de direção/exploração do trabalho de outras, mesmo que tenham funções parciais de produtores diretos, como nota Erick O. Wright; ademais, outras pessoas podem estar de um lado no início da carreira e passar ao outro lado mais tarde etc. 
42. Trata-se das categorias 1210 (Dirigentes de empresas), 1219 (Dirigentes empregadores com mais de cinco empregados), 1220 (Diretores de produção e operação) e 1230 (Diretores de áreas de apoio).

43. Por meio de análise de correspondência binária, analisamos a distribuição espacial das CS52 e CS54 nas metrópoles do Rio de Janeiro e de São Paulo, a partir dos dados do Censo Demográfico de 2010. Também espacialmente as duas CS estão muito mais próximas das categorias médias do que das populares. Ademais, em termos das rendas média e mediana as duas se distinguem claramente das classes populares (trabalhadores dos serviços e classe operária).

44. Trata-se das CS5x e CS6x, que agrupam agentes de vigilância e militares de baixa patente, comerciários, pessoal de serviços diretos a particulares, empregados domésticos, operários, trabalhadores agrícolas, motoristas etc.

45. Setembro é o mês de referência da PNAD.

46. É preciso considerar a tendência ao longo do período, mais do que as variações de um ano a outro, que resultam muitas vezes de flutuações aleatórias ligadas ao tamanho das amostras para cada região analisada.

47. Os dados relativos à metrópole parisiense usados aqui a título de comparação podem ser encontrados em Préteceille (2016).

48. De fato, se incluirmos as categorias superiores suprimidas da CS37, chega-se a 1,5\% dos ocupados no Rio e 2,2\% em São Paulo em 2002.

49. Sobre a "desterceirização" na CSN e na Caixa Econômica Federal, ver Dias e Oliveira (2011). Outro exemplo desse processo foi a recontratação, pela Fiat de Betim, de 2,6 mil trabalhadores terceirizados da área de logística da fábrica, cujas atividades haviam sido terceirizadas 15 anos antes. A fábrica precisou contratar também gestores de logística para a supervisão das atividades. Ver http:/ / www.autodata.com.br/noticias / 16347 / fiat-adota-desterceirizacao-na-logistica-em-betim-mg (consultado em fevereiro de 2016). Em 2006, a TAM Linhas Aéreas "desterceirizou" cerca de cinco mil funcionários em nome da "boa governança corporativa" (http://www.ihu.unisinos.br/noticias / 1979-tam-volta-atras-na-terceirizacao-desterceirizacao-ganha-corpo-segundo-consultor, consultado em fevereiro de 2016).

50. Dados disponíveis em http://convergenciacom.net/pdf/mapa-ensino-superiorbrasil-2015.pdf, p. 7 (acessado em março de 2016).

51. Entre 2002 e 2011, o número de programas de pós-graduação stricto sensu no Brasil cresceu 84\%. Em 2011, 83\% dos programas existentes eram de universidades públicas. Dados em Cirani et al. (2015).

52. Esta "classe média", ainda que muito presente na literatura, não tem uma definição sociológica precisa, menos ainda uma medida empírica. Se tomarmos como aproximação o conjunto da categoria socioprofissional dos cadres e profissões intelectuais superiores (CS3), o conjunto das classes médias é mais de duas vezes mais numeroso; e é mais de três vezes se tomarmos uma aproximação mais restrita às profissões de estatuto superior.

53. Fonte: bases de dados da RAIS tabulados para este estudo.

54. Em 2012 o Estado do Rio foi o que menos investiu em saúde pública no Brasil, segundo o IBGE: 7,2\% do orçamento, contra 10,1\% em São Paulo e 16,3\% em Minas Gerais. E o investimento em educação tem estado apenas ligeiramente acima do limite constitucional de 25\%, contra perto de 30\% em São Paulo. Ver IBGE (2013). 


\section{REFERÊNCIAS BIBLIOGRÁFICAS}

ALBUQUERQUE, José Augusto G. (coord.). (1977), Classes Médias e Política no Brasil. São Paulo, Paz e Terra.

ARISTÓTELES. (2008), Política. New York, Cosmo Classics (Trad. Benjamin Jowett).

BARBOSA, Maria L. (1998), “Para Onde Vai a Classe Média: Um Novo Profissionalismo no Brasil?" Tempo Social, vol. 10, no 1, pp. 129-142.

BARROS, Ricardo Paes de et al. (2011), A Nova Classe Média Brasileira: Desafios que Representa para a Formulação de Políticas Públicas. Brasília, Secretaria de Assuntos Estratégicos.

BARTELT, Dawid D. (org.). (2013), A “Nova Classe Média" no Brasil como Conceito e Projeto Político. Rio de Janeiro, Fundação Heinrich Böll.

BAUDELOT, Christian; TOISER, Jacques. (1974), La Petite Bourgeoisie en France. Paris, F. Maspero.

BAUMAN, Zygmunt. (2003), Modernidade Líquida. Rio de Janeiro, Zahar.

BIRDSALL, Nancy; GRAHAM, Carol; PETTINATO, Stefano. (2000), Stuck in the Tunnel: Is Globalization Muddling the Middle Class? Disponível em http://www.brookings.edu/es/dynamics/papers/middleclass/midclass.pdf. Acessado em novembro de 2015 .

BOLTANSKI, Luc. (1982), Les Cadres. La Formation d'un Groupe Social. Paris, Minuit.

BONELLI, Maria da G. (1989), A Classe Média, do "Milagre" à Recessão: Mobilidade Social, Expectativas e Identidade Coletiva. São Paulo, IDESP.

; DONATONI, Silvana. (1996), "Os Estudos sobre Profissões nas Ciências Sociais Brasileiras". BIB, Revista Brasileira de Informações Bibliográficas em Ciências Sociais, no 41, pp. 109-142.

BOSC, Serge. (2008), Sociologie des Classes Moyennes. Paris, La Découverte, collection "Repères".

BOUDON, Raymond. (1981), A Desigualdade de Oportunidades. Brasília, Ed. UnB.

BOURDIEU, Pierre. (1979), La Distinction: Critique Sociale du Jugement. Paris, Minuit.

; PASSERON, Jean-Claude. (1994), "Strategies de Reproduction e Modes de Domination". Actes de la Recherche in Sciences Sociales, vol. 105, no 1, pp. 3-12.

BUSSOLO, Maurizio; DE HOYOS, Rafael; MEDVEDEV, Denis. (2008), "Is the Developing World Catching Up? Global Convergence and National Rising Dispersion". Policy Research Working Paper no 4733, World Bank.

BUSSOLO, Maurizio; MALISZEWSKA, Maryla; MURARD, Elie. (2014), “The Long-awaited Rise of the Middle Class in Latin America Is Finally Happening". Policy Research Working Paper no 6912, World Bank.

CARVALHAES, Flavio A. O. (2015), "A Tipologia Ocupacional Erikson-Goldthorpe-Portocarrero (EGP): Uma Avaliação Analítica e Empírica". Estado e Sociedade, vol. 30, no 3, pp. 673-303. 
CASTELLS, Manuel. (2013), Redes de Indignação e Esperança. Movimentos Sociais na Terra da Internet. Rio de Janeiro, Zahar.

CHAUVEL, Louis. (2006), Les Classes Moyennes à la Dérive. Paris, Seuil.

CHENU, Alain. (2005). Sociologie des Employés. Paris, La Découverte, collection Repères.

CIRANI, Claudia B.; CAMPANARIO, Milton A.; SILVA, Heloísa H. (2015), “A Evolução do Ensino da Pós-Graduação Senso Estrito no Brasil: Análise Exploratória e Proposições para Pesquisa". Avaliação, vol. 20, no 1, pp. 163-187.

CLEMENT, Matthieu; ROUGIER, Éric. (2015), “Classes Moyennes et Emergence en Asie de l'Est: Mesures et Enjeux”. Mondes en Développement, vol. 169, no 1, pp. 31- 45.

DAHRENDORF, Ralf. (1962), Las Classes Sociales y su Conflicto en la Sociedad Industrial. Madrid, Ediciones Rialp.

DARBON, Dominique. (2012), “Classe(s) Moyenne(s): Une Revue de la Littérature (Un Concept Utile pour Suivre les Dynamiques de l'Afrique)". Afrique Contemporaine, vol. 244, no 4, pp. 33-51.

DESROSIERES, Alain; THEVENOT, Laurent. (1988), Les Catégories Socio-professionnelles. Paris, La Découverte, collectionRepères.

DIAS, Sabrina M.; OLIVEIRA, Ricardo G. (2011), Depois da Terceirização, a Desterceirização: Comparação dos Processos na CSN e na Caixa. Anais do XV Congresso Brasileiro de Sociologia. Disponível em file:///C:/Users/acardoso/Downloads/sbs2011ãGT31_ Sabrinaãde_OliveiraãMoura_Dias.pdf.Acessado em fevereiro de 2016.

DINIZ, Marli. (1998), "Repensando a Teoria da Proletarização dos Profissionais". Tempo Social, vol. 10, no 1, pp. 165-184.

EDER, Klaus. (2001), “A Classe Social Tem Importância no Estudo dos Movimentos Sociais? Uma Teoria do Radicalismo da Classe Média". Revista Brasileira de Ciências Sociais, vol. 16, no 46, pp. 5-27.

EHRENREICH, Barbara. (1994), O Medo da Queda. Ascensão e Crise da Classe Média. São Paulo, Scritta.

ERIKSON, R.; GOLDTHORPE, J. H. (1992), The Constant Flux: A Study of Class Mobility in Industrial Societies. Oxford, Oxford University Press.

FIGUEIREDO, Angela. (2009), Classe Média Negra: Trajetórias e Perfis. Salvador, EDUFBA.

FLEURY, Affonso. (1990), “Análise a Nível de Empresa dos Impactos da Automação sobre a Organização da Produção e do Trabalho", in A. Fleury et al. (orgs.), Gestão da Empresa, Automação e Competitividade. Novos Padrões de Organização e de Relações do Trabalho. Brasília, Ipea/Iplan.

FRANCO, Rolando; HOPENHAYN, Martín; LEÓN, Arturo. (2010), Las Clases Medias en América Latina: Retrospectiva y Nuevas Tendencias. México, Siglo XXI/Cepal.

GITAHY, Leda. (org.). (1994), Reestructuración Productiva, Trabajo y Educación en América Latina. Lecturas de Educación y Trabajo (3). Buenos Aires/Campinas, Red CIID-CENEP.

GRÜN, Roberto. (1994), “O Estreitamento das Classes Médias Brasileiras”. Revista Brasileira de Ciências Sociais, vol. 25, no 9, pp. 130-133. 
(1996). “O Medo do Desemprego e as Mudanças no Universo Simbólico das Classes Médias Brasileiras”, in E. Reis; M. H. T. Almeida; P. Fry (orgs.), Política e Cultura. Visões do Passado e Perspectivas Contemporâneas. São Paulo, Hucitec/Anpocs, pp. 127-141.

. (1998), "A Classe Média no Mundo do Neoliberalismo". Tempo Social, vol. 10, no1, pp. 143-163.

(1999), “Modelos de Empresa, Modelos de Mundo: Sobre Algumas Características Culturais da Nova Ordem Econômica e da Resistência a Ela. Revista Brasileira de Ciências Sociais, vol. 14, no 41, pp. 121-140.

HAMNETT, Chris. (1994), "Social Polarisation in Global Cities: Theory and Evidence". Urban Studies, vol. 33, no 8, pp. 401-424.

. (2003), Unequal City. London in the Global Arena. London, Routledge.

HASENBALG, Carlos A.; SILVA, Nelson do Valle. (1988), Estrutura Social, Mobilidade e Raça. São Paulo, Vértice.

HASENBALG, Carlos; SILVA, Nelson do Valle (orgs.). (2003), Origens e Destinos: Desigualdades Sociais ao Longo da Vida. Rio de Janeiro, TopBooks.

IBGE (Instituto Brasileiro de Geografia e Estatística). (2003), Estatísticas do Século XX. Rio de Janeiro, IBGE.

. (2013), Perfil dos Estados Brasileiros 2013. Rio de Janeiro, IBGE.

JACQUEMOT, Pierre. (2004), “Les Classes Moyennes en Afrique. Introduction Thématique", Afrique Contemporaine, vol. 244, no 4, pp. 13-15.

KHARAS, Homi. (2010), “The Emerging Middle Class in Developing Countries. OECD Development Centre Working Paper no 258. Paris, OECD.

LIMA, Diana N. (2008), Sujeitos e Objetos do Sucesso. Antropologia do Brasil Emergente. Rio de Janeiro, Garamond/Faperj.

MARQUES, Eduardo; SCALON, Celi; OLIVEIRA, Maria A. (2008), “Comparando Estruturas Sociais no Rio de Janeiro e em São Paulo". DADOS - Revista de Ciências Sociais, vol. 51, no1, pp. 215-238.

MAURIN, Éric. (2009), La Peur du Déclassement. Une Sociologie des Récessions. Paris, Seuil.

MENDRAS, Henri. (1988), La Seconde Révolution Française 1965-1984. Paris, Gallimard.

MILANOVIC, Branko; YITZHAKI, Shlomo. (2002), Decomposing World Income Distribution: Does the World Have a Middle Class? Review of Income and Wealth, vol. 2, no 48, pp. $155-178$.

NERI, Marcelo C. (2008), A Nova Classe Média. Rio de Janeiro, FGV. Disponível em http://www.cps.fgv.br/ibrecps/M3/M3_TextoFinal.pdf. Acessado em fevereiro de 2016.

. (2010), A Nova Classe Média. O Lado Brilhante dos Pobres. Rio de Janeiro, FGV. Disponível em http://www.cps.fgv.br/ibrecps/ncm2010/NCM_Pesquisa_FORMATADA.pdf. Acessado em fevereiro de 2016.

OLIVEIRA, Francisco de. (1987), O Elo Perdido. Classe e Identidade de Classe. São Paulo, Brasiliense. 
PASTORE, José; SILVA, Nelson do Valle. (2000), Mobilidade Social no Brasil. São Paulo, Makron Books.

PEUGNY, Camille. (2009), Le Déclassement. Paris, Grasset.

POCHMANN, Marcio. (2012), Nova Classe Média? O Trabalho na Base da Pirâmide Social Brasileira. São Paulo, Boitempo (caps. 3 e 4).

(2014), O Mito da Grande Classe Média. São Paulo, Boitempo (caps. 3 e 4).

POUlANTZAS, Nicos. (1974), Les Classes Sociales dans Capitalisme Aujourd'hui. Paris, Seuil.

PRANDI, Reginaldo. (1982), Os Favoritos Degradados. Ensino Superior e Profissões de Nível Universitário no Brasil de Hoje. São Paulo, Loyola.

PRESSMAN, Steven. (2007), “The Decline of the Middle Class: An International Perspective". Journal of Economic Issues, vol. XLI, no 1, pp. 181-200.

PRÉTECEILLE, Edmond. (1995),“Division Sociale de 1’Espace et Globalisation. Le Cas de la Métropole Parisienne". Sociétés Contemporaines, no 22-23, pp. 33-67.

(2006), “La Ségrégation Sociale a-t-elle Augmenté? La Métropole Parisienne entre Polarisation et Mixité". Sociétés Contemporaines, no 62, pp. 69-93.

(2016), “Les évolutions de la Ségrégation Socioprofessionnelle dans la Métropole Parisienne 1999-2008". Paris, Observatoire Sociologique du Changement.

PRÉTECEILLE, Edmond; CARDOSO, Adalberto M. (2008), “Río de Janeiro y São Paulo: Ciudades Duales? Comparación con Paris". Ciudad y Territorio, Estudios Territoriales, vol. XL, pp. 617-640.

PRÉTECEILLE, Edmond; RIBEIRO, Luiz Cesar de Queiroz. (1999), “Tendências da Segregação Social em Metrópoles Globais e Desiguais: Paris e Rio de Janeiro nos Anos 80". Revista Brasileira de Ciencias Sociais, no 40, pp. 143-162.

QUADROS, Waldir J. (1985), A Nova Classe Média Brasileira: 1950-1980. Dissertação (Mestrado em Economia), Instituto de Economia, Unicamp, Campinas. Disponível em file:/ / C:/Users/acardoso/Downloads/QuadrosWaldirJos\%C3\%A9de\% 20(1).pdf. Acessado em fevereiro de 2016.

. (1991), O “Milagre Brasileiro” e a Expansão da Nova Classe Média. Tese (Doutorado em Economia), Instituto de Economia, Unicamp, Campinas.

. (2007), "A Dinâmica da Classe Média", in G. Dupas (org.), Espaços para o Crescimento Sustentado da Economia Brasileira. São Paulo, Editora Unesp/IEEI, pp. 159-185.

. (2008), "A Evolução Recente da Estrutura Social Brasileira". Texto para Discussão, n148, Instituto de Economia, Unicamp.

RIBEIRO, Carlos Antonio C. (2009), Desigualdade de Oportunidade no Brasil. Belo Horizonte, Argumentum.

. (2014), “Estrutura de Classes e Mobilidade Social no Brasil Contemporâneo”. Sociologias, vol. 37, pp. 54-70.

; SCALON, Celi. (2003), "Class Mobility in Brazil from a Comparative Perspective", in M. D'Alva Kinzo; J. Dunkerley (orgs.), Brazil since 1985. Economy, Polity and Society. London, ILAS, pp. 200-231. 
. (2001), "Mobilidade de Classe no Brasil em Perspectiva Comparada". DADOS Revista de Ciências Sociais, vol. 44, no 1, pp. 53-96.

RICCI, Rudá. (2013), Lulismo. Da era dos Movimentos Sociais à Ascensão da Nova Classe Média. Brasília, Astrogildo Pereira; Rio, Contraponto.

ROMANELLI, Geraldo. (1985), Famílias de Camadas Médias: A Trajetória da Modernidade. Tese (Doutorado em Ciências Sociais), FFLCH/USP, São Paulo.

SALAMA, Pierre. (2014), As Classes Médias Podem Dinamizar o Crescimento do PIB nas Economias Emergentes? Estudos Avançados, vol. 28, no 81, pp. 7-22.

SALATA, André R. (2016), A Classe Média Brasileira: Posição Social e Identidade de Classe. Rio de Janeiro, Faperj/Letra Capital, e-pub.

SANTOS, José Alcides F. (2002), Estrutura e Posições de Classe no Brasil. Belo Horizonte, UFMG/IUPERJ-UCAM.

SCALON, Maria Celi. (1999), Mobilidade Social no Brasil. Rio de Janeiro, Revan.

; Salata, André R. (2012), Uma Nova Classe Média no Brasil da Última Década? O Debate a partir da Perspectiva Sociológica. Sociedade E Estado, vol. 27, no 2, pp. 387-407.

SCHWARTZ, Olivier. (2011), Peut-on Parler de Classes Populaires? La Vie des Idées.fr Disponível em http://www.laviedesidees.fr/Peut-on-parler-des-classes.html. Acessado em maio de 2016.

SCHWARTZMAN, Simon. (1981), O Pensamento Nacionalista e os "Cadernos de Nosso Tempo". Brasília, Câmara de Deputados e Biblioteca do Pensamento Brasileiro, Biblioteca do Pensamento Político Republicano, vol. 6. Disponível em http://www. schwartzman.org.br/simon/cadernos.htm. Acessado em fevereiro de 2016.

SILVA, Nelson do Valle. (1988), Uma Classificação Ocupacional para o Estudo da Mobilidade e da Situação de Trabalho no Brasil. Rio de Janeiro, IUPERJ (mimeo).

. (2004), Cambios Sociales y Estratificación el Brasil Contemporáneo (1945-1999).Santiago, Cepal.

SIMÕES, Solange D. (1985), Deus, Pátria e Família: As Mulheres no Golpe de 1964. Petrópolis, Vozes.

SINGER, André. (2009), "Raízes Sociais e Ideológicas do Lulismo". Novos Estudos CEBRAP, no 85, pp. 83-102.

SINGER, Paul I. (1981), Dominação e Desigualdade. Estrutura de Classes e Repartição da Renda no Brasil. São Paulo, Paz e Terra.

. (1988), "Reflexões sobre Inflação, Conflito Distributivo e Democracia", in F. W. Reis; G. O'Donnell (orgs.), Democracia no Brasil: Dilemas e Perspectivas. São Paulo, Vértice.

SOUZA, Amaury; LAMOUNIER, Bolivar. (2010), A Classe Média Brasileira. Ambições, Valores e Projetos de Sociedade. Rio de Janeiro, Elsevier; Brasília, CNI.

SOUZA, Jessé. (2010), Os Batalhadores Brasileiros: Nova Classe Média ou Nova Classe Trabalhadora? Belo Horizonte, UFMG Editora. 
STORPER, Michael. (1997), The Regional World. Territorial development in a Global Economy. New York, Guilford.

SULLIVAN, Teresa; WARREN, Elizabeth; WESTBROOK, Jay L. (2001), “Une Prospérité Précaire: Sur les Situations Financières Critiques dans la Classe Moyenne". Actes de la Recherche en Sciences Sociales, vol. 138, no 3, pp. 19-33.

URRY, John. (2000), Sociology beyond Societies: Mobilities for the Twenty-first Century. London; New York, Routledge.

VAINER, Carlos et al. (2013), Cidades Rebeldes. Passe Livre e as Manifestações que Tomaram as Ruas do Brasil. São Paulo, Boitempo.

WIETZKE, Borge; SUMNER, Andy. (2014), The Political and Social Implications of the "New Middle Classes" in Developing Countries: A Literature Review and Avenues for Future Research. Disponível em http://www.gc2014.org/wp-content/uploads/2014/01/GC2014_Background-Paper.pdf . Acessado em novembro de 2015.

WRIGHT, Erick Olin. (1985), Classes. London, Verso.

WRIGHT MILLS, Charles. (1951), White Collar. The American Middle Classes. New York, Oxford University Press. 


\section{RESUMO}

Classes Médias no Brasil: Do que se Trata? Qual seu Tamanho? Como Vem Mudando?

$\mathrm{O}$ artigo procura responder à seguinte questão: até que ponto a melhoria nas condições de vida no país entre 2002 e 2014 resultou de mudanças na estrutura de posições de trabalhadores e trabalhadoras na divisão social do trabalho, a ponto de podermos sustentar que o Brasil tornou-se um país de classe média? Para isso, discute-se a literatura internacional e nacional sobre classes médias, incluind o o debate sobre a "nova classe média"; apresenta-se inovadora alternativa sociológica de construção da estrutura de classes no Brasil a partir da Classificação Socioprofissional francesa; mostra-se empiricamente a evolução dessa estrutura; e conclui-se que as classes médias cresceram significativamente no período, mas o país está muito longe de ser "um país de classe média".

Palavras-chave: classes médias; Brasil; França; estrutura de classes; estratificação social

\section{ABSTRACT \\ The Brazilian Middle Classes: Who Are They? How Extensive Are They? How Have They Evolved?}

The following article aims to address the extent to which improvements in the quality of life in Brazil from 2002 to 2014 resulted from shifts in the structure of workers' roles in the social division of labor, and whether or not Brazil became a country of middle classes in the process. To do so, national and international literature on middle classes is examined, as is the debate on the "new middle class". An innovative sociological alternative for shaping the class structure based on the French socio-professional classification system is suggested, while an empirical study is used to demonstrate the evolution of this structure. The article concludes that the middle classes grew significantly during the period, however Brazil is far from constituting a "country of middle classes".

Abstract: middle classes; Brazil; France; class structures; social stratification 
RÉSUMÉ

Classes Moyennes au Brésil: De Quoi s'agit-il? Quelle est Leur Étendue? Comment se Transforment-elles?

Cet article cherche à répondre à la question suivante : dans quelle mesure l'amélioration des conditions de vie dans le pays entre 2002 et 2014 est-elle le résultat de transformations des positions occupées par les travailleuses et les travailleurs au sein de la division sociale du travail, au point d'entendre dire que le Brésil serait devenu un pays de classes moyennes? Nous nous baserons à cette fin sur la littérature nationale et internationale sur les classes moyennes, mais également sur le débat relatif à la "nouvelle classe moyenne". Nous proposons une vision sociologique innovante de la construction de la structure de classes au Brésil en nous fondant sur la Classification socioprofessionnelle française pour analyser de façon empirique l'évolution de cette structure et en conclure que les classes moyennes ont connu une croissance significative durant la période, mais que le pays est encore loin d'être "un pays de classes moyennes".

Mots-clés: classes moyennes; Brésil; France; structure de classes; stratification sociale

\section{RESUMEN}

Las Clases Medias en Brasil: ¿Qué son? ¿Qué Dimensiones Tienen? ¿Cómo ha Sido su Evolución?

El artículo busca responder a la siguiente pregunta: ¿en qué medida la mejora en las condiciones de vida en el país entre 2002 y 2014 ha provocado cambios en la estructura de los puestos laborales de los trabajadores y las trabajadoras dentro de la división social del empleo hasta el punto de poder afirmar que Brasil se ha convertido en un país de clase media? Para ello, se discute la literatura internacional y nacional sobre clases medias, incluido el debate sobre la "nueva clase media": se presenta una innovadora alternativa sociológica de construcción de la estructura de clases en Brasil a partir de la clasificación socio-profesional francesa, se muestra empíricamente la evolución de dicha estructura y se concluye que, aunque las clases medias han crecido de forma significativa en dicho período, Brasil está muy lejos de ser "un país de clase media".

Palabras clave: clases medias; Brasil; Francia; estructura de clases; estratificación social 